\title{
New insights on Neolithic food and mobility patterns in Mediterranean coastal populations
}

\author{
Gwenaëlle Goude $^{1}$ (1) ～Domingo C. Salazar-García 2,3,4,5,6 ｜ Robert C. Power \\ Maïté Rivollat $^{7,8}$ | Lionel Gourichon ${ }^{9}$ | Marie-France Deguilloux ${ }^{8}$ | \\ Marie-Hélène Pemonge ${ }^{8}$ | Laurent Bouby ${ }^{10}$ | Didier Binder ${ }^{9}$ \\ ${ }^{1}$ Aix Marseille Univ, CNRS, Minist. Culture, LAMPEA, Aix-en-Provence, France \\ ${ }^{2}$ Grupo de Investigación en Prehistoria IT-1223-19 (UPV-EHU)/IKERBASQUE-Basque Foundation for Science, Vitoria, Spain \\ ${ }^{3}$ Aix Marseille Univ, IMERA, Marseille, France \\ ${ }^{4}$ Department of Geological Sciences, University of Cape Town, Cape Town, South Africa \\ ${ }^{5}$ Department of Human Evolution, Max Planck Institute for Evolutionary Anthropology, Leipzig, Germany \\ ${ }^{6}$ Departament de Prehistòria, Arqueologia i Història Antiga, Universitat de València, València, Spain \\ ${ }^{7}$ Department of Archaeogenetics, Max Planck Institute for the Science of Human History, Jena, Germany \\ ${ }^{8}$ Bordeaux University, Pessac, France \\ ${ }^{9}$ Université Côte d'Azur, CNRS, CEPAM, France \\ ${ }^{10}$ ISEM-Université Montpellier, CNRS, EPHE, IRD, Montpellier, France
}

\section{Correspondence}

Gwenaëlle Goude, Aix Marseille Univ, CNRS, Minist. Culture, LAMPEA, Aix-en-Provence,

France.

Email: goude@mmsh.univ-aix.fr

Funding information

ETICALP programme; Institut Danone France/ Fondation pour la Recherche Médicale; project INTERACT, Grant/Award Number: ANR-

17-FRAL-0010

\begin{abstract}
Objectives: The aims of this research are to explore the diet, mobility, social organization, and environmental exploitation patterns of early Mediterranean farmers, particularly the role of marine and plant resources in these foodways. In addition, this work strives to document possible gendered patterns of behavior linked to the neolithization of this ecologically rich area. To achieve this, a set of multiproxy analyses (isotopic analyses, dental calculus, microremains analysis, ancient DNA) were performed on an exceptional deposit $(n=61)$ of human remains from the Les Bréguières site (France), dating to the transition of the sixth to the fifth millennium BCE.
\end{abstract}

Materials and Methods: The samples used in this study were excavated from the Les Bréguières site (Mougins, Alpes-Maritimes, France), located along the southeastern Mediterranean coastline of France. Stable isotope analyses (C, N) on bone collagen (17 coxal bones, 35 craniofacial elements) were performed as a means to infer protein intake during tissue development. Sulfur isotope ratios were used as indicators of geographical and environmental points of origin. The study of ancient dental calculus helped document the consumption of plants. Strontium isotope analysis on tooth enamel ( $n=56$ ) was conducted to infer human provenance and territorial mobility. Finally, ancient DNA analysis was performed to study maternal versus paternal diversity within this Neolithic group $(n=30)$.

Results: Stable isotope ratios for human bones range from -20.3 to $-18.1 \%$ for $C$, from 8.9 to $11.1 \%$ o for $\mathrm{N}$ and from 6.4 to $15 \%$ o for $\mathrm{S}$. Domestic animal data range 
from -22.0 to $-20.2 \%$ o for C, from 4.1 to $6.9 \%$ o for $\mathrm{N}$, and from 10.2 to $12.5 \%$ o for S. Human enamel ${ }^{87} \mathrm{Sr} /{ }^{86} \mathrm{Sr}$ range from 0.7081 to 0.7102 , slightly wider than the animal range (between 0.7087 and 0.7096). Starch and phytolith microremains were recovered as well as other types of remains (e.g., hairs, diatoms, fungal spores). Starch grains include Triticeae type and phytolith includes dicotyledons and monocot types as panicoid grasses. Mitochondrial DNA characterized eight different maternal lineages: $\mathrm{H} 1$, H3, HV (5.26\%), J (10.53\%), J1, K, T (5.2\%), and U5 (10.53\%) but no sample yielded reproducible $Y$ chromosome SNPs, preventing paternal lineage characterization.

Discussion: Carbon and nitrogen stable isotope ratios indicate a consumption of protein by humans mainly focused on terrestrial animals and possible exploitation of marine resources for one male and one undetermined adult. Sulfur stable isotope ratios allowed distinguishing groups with different geographical origins, including two females possibly more exposed to the sea spray effect. While strontium isotope data do not indicate different origins for the individuals, mitochondrial lineage diversity from petrous bone DNA suggests the burial includes genetically differentiated groups or a group practicing patrilocality. Moreover, the diversity of plant microremains recorded in dental calculus provide the first evidence that the groups of Les Bréguières consumed a wide breadth of plant foods (as cereals and wild taxa) that required access to diverse environments. This transdisciplinary research paves the way for new perspectives and highlights the relevance for novel research of contexts (whether recently discovered or in museum collections) excavated near shorelines, due to the richness of the biodiversity and the wide range of edible resources available.

\section{KEYWORDS}

ancient DNA, dental calculus, marine resources, radiocarbon date, stable isotopes

\section{INTRODUCTION}

The Neolithic is the final periodic division of the Stone Age, which embodies the advent and development of plant cultivation and animal domestication; it also marks a new step in cultural and economic changes that led to profound biological and social modifications in human societies. Studying the diversity of dietary practices as well as their social implications is a relevant way to understand the relationships between the environment and the potential status of individuals within a society. Among these changes, the exploitation of the environment (domestic vs. wild; animal vs. plant; aquatic vs. terrestrial) and the respective social position of females and males are of importance in understanding the rise of new precursory markers of demographic expansion and economic development. The identity of females in Neolithic societies is commonly debated within the context of gender-based division of labor and contributions to subsistence. Ethnological comparisons (Umezaki et al., 2016), modeling of technical-economic systems (Hansen, Jensen, \& Skovsgaard, 2015) and osteological analyses (Holden \& Mace, 1999) put forward different arguments for the possible roles of each sex (Cohen, 2016). One of the most common hypotheses, sex-based division of task and food acquisition, argues that differential access to resources is determined by sexual division of labor, with males consuming greater amounts of meat and females consuming greater amounts of plant foods (Berbesque, Marlowe, \& Crittenden, 2011). Beyond this possible dichotomy, differences in food consumption between females and males have been explored through stable isotope ratios obtained on Neolithic human bone (Goude et al., 2013; Rey et al., 2019; Rey, Goude, \& Rottier, 2017). Carbon and nitrogen stable isotope data indicate either a significant difference in animal protein consumption between males and females (Rey et al., 2017) or a wider range of ratios recorded in female bones. The latter may have been linked to the diversity of food consumed and/or mobility and visited environments (Goude et al., 2013).

Mobility is also an important component of dietary patterns and environment exploitation. Studies, based on strontium isotopic data $\left({ }^{87 / 86} \mathrm{Sr}\right)$, have demonstrated higher female mobility among Neolithic communities in northern Europe (German/Alsace regions) that may be linked to patrilocal residence rules (Bentley et al., 2012). Recent ${ }^{87 / 86} \mathrm{Sr}$ data from northwestern France (Touraine area; site of Le Vigneau) found that females tended to move between childhood and adolescence, while at the same time carbon and nitrogen isotopic 
ratios $\left(\delta^{13} \mathrm{C}, \delta^{15} \mathrm{~N}\right)$ underlined a homogeneous diet, based on domestic animal resources (Goude et al., 2019). On the other hand, while ${ }^{87 / 86} \mathrm{Sr}$ of Neolithic individuals from the Paris Basin (site of Gurgy) did not provide evidence for differential mobility, bone $\delta^{13} \mathrm{C}$ and $\delta^{15} \mathrm{~N}$ indicated significant differences between the sexes, with females consuming less animal protein than males (Rey et al., 2017). Individual differences in mobility and dietary patterns could also be a consequence of life history. In the examples mentioned above, mobility is inferred from residence during childhood and adolescence when tooth enamel is still being formed, while diet is evaluated on adult bone collagen reflecting a mean protein intake during a longer period of time. In the case of dietary change, the scale and dynamic of food consumption can be missed if bioarchaeological investigations do not target the timing of these changes.

Another widely debated issue is the role of marine food consumption, particularly in the Mediterranean region (Salazar-García, Fontanals-Coll, Goude, \& Subirà, 2018). The impact of marine resources in early farming communities has been widely discussed for decades (Richards \& Schulting, 2003; Tauber, 1981). In Europe, many isotopic studies track the Mesolithic-Neolithic dietary transition, particularly on coastal sites. The isotopic shift observed between the Mesolithic hunter-gatherer-fishers and Neolithic farmers has led many authors to interpret an "abandonment" of maritime resources (Schulting \& Richards, 2002), or taboos against the consumption of seafood (Thomas, 2003). These findings have, however, not ben replicated across the European continent. For example in the Danube Gorges and in some parts of Northern Europe (Milner, Craig, Bailey, Pedersen, \& Andersen, 2004), relative continuity in aquatic resource consumption is reported. On the other hand, particularly in the Mediterranean area, isotopic data collected from Mesolithic sites suggest high levels of dietary diversity within sites (Guiry et al., 2016; SalazarGarcía et al., 2018) leading to a less distinct neolithization pattern. The expansion of analyses of Mediterranean Early and Middle Neolithic sites has provided enough data to demonstrate the diversity of dietary patterns among these populations (Salazar-García et al., 2018). Protein consumption typically emphasized terrestrial resources but there are exceptional examples of marine use (Salazar-García, Romero, García-Borja, Subirà, \& Richards, 2016). Notwithstanding, current evidence indicates that this variability seems to decline by the end of the Neolithic.

Consequently, the reassessment of sites in south-eastern France, such as Les Bréguières (fig. 1; Provost et al., 2017) is of importance and provides a unique opportunity to investigate dietary variability in relation to mobility, social relationships, and environmental exploitation in the Mediterranean area. Previous analyses of Early and Middle Neolithic sites in the area (review in Goude \& Fontugne, 2016) have demonstrated a subsistence economy geared toward terrestrial resources; however, most of the sites were located at a higher altitude than Les Bréguières. The short distance to the sea as well as landscape morphology (e.g., cliffs, marshes) are important parameters to consider because these features provide regular access to the shoreline and/or regular contact with other coastal communities. These parameters have, for example, been considered for a Corsican
Mesolithic study, where only individuals found along the shoreline consumed maritime resources (Goude et al., 2017). However, some degree of caution in these interpretations is warranted as populations adapted to coastlines may not be reliant on maritime resources. For example, Early and Middle Neolithic sites in Liguria demonstrate a reduced consumption of maritime resources, despite shoreline proximity (Goude, Binder, \& Del Lucchese, 2011-2013; Goude, Dori, Sparacello, Starnini, \& Varalli, 2020; Mannino, Talamo, Goude, \& Richards, 2018; Salazar-García et al., 2014).

Considering the importance (size, location, sepulchral mode, and preservation) and the chronocultural attribution of the human remains recovered from Les Bréguières (cf. site description in the materials and method section), this collection was included within a multidisciplinary project (IDF/FRM 2016-2017 program; http://lampea. cnrs.fr/spip.php?article3473) to explore diet, mobility and social organization during the Early Neolithic. The work carried on Les Bréguières endeavors to new data on two main issues: (a) the work will explore diet in relation to mobility and social organization with specific reference to the role of maritime and plant resource consumption; (b) evidence for sex-specific variation in dietary behavior.

\section{2 | MATERIALS AND METHODS}

\subsection{Les Bréguières}

The Les Bréguières site is located along the Mediterranean coastline of southeastern France, near the Alpes-Maritimes mountains. The site is located in a quarry and was discovered and excavated by Maurice Sechter in 1965-1966 (Figure 1a). The site is a sepulchral gallery (Figure 1b) and, at the time of discovery, an appropriate excavation method for human remains was not employed. However, the material was carefully removed, packed, and stored and it was possible to proceed with new analyses within the framework of a formal bioarchaeological research program (ETICALP, dir. D. Binder 2007-2014). Part of the site, including the initial entrance used during the Neolithic, was destroyed by the quarry activities and only a portion of the site was excavated.

\subsection{The human remains and associated materials}

The area excavated yielded approximately 61 individuals found in a collective burial. The site, despite partial destruction, is one of the oldest of this type dated to the Neolithic in the north-western Mediterranean and the oldest in the south of France. Human remains at this site were commingled. Infants were not among these materials. Sex could be determined from several os coxae $(n=19)$, and these bones also made it possible to estimate the age in a few selected individuals ( $n=13$ ). Pre-adult remains were recovered from the site, but age has not been estimated in these individuals (SI 1a and 1b; Provost et al., 2017). Very few artifacts (lithic tools, faunal remains and worked seashells) were associated with the human deposits and few pottery 

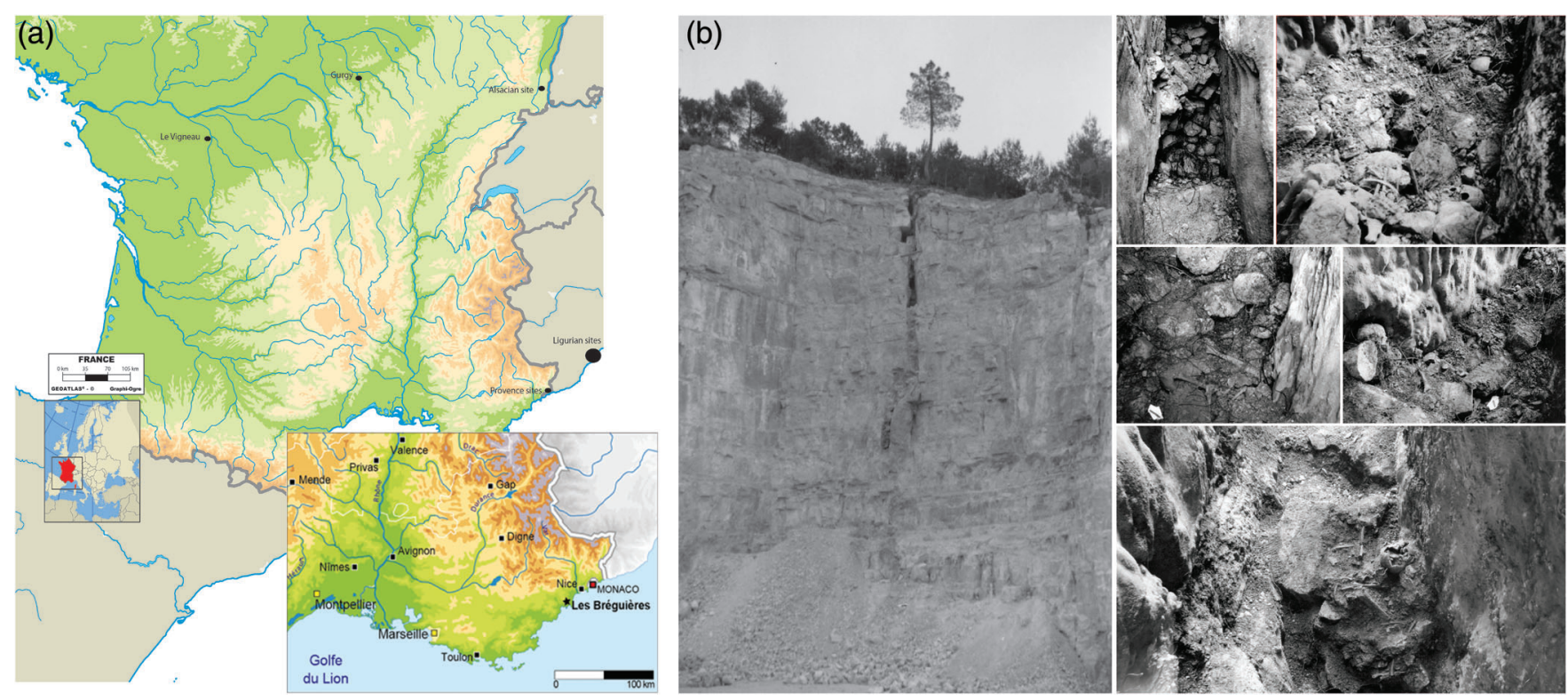

FIGURE 1 (a) Location of the site studied and the areas with Neolithic sites mentioned in the text. (b) Outside view of the sepulchral gallery (left) and inside the gallery during the excavation (right) showing the different human remains deposits (photos taken in 1966-1967 by M. Sechter; more details in Provost et al., 2017)

shards were found in the deposits postdating the burial. Caprine (mainly sheep) and suids dominate the faunal assemblage; a few dog and cattle elements were also identified as well as wild species (including wild boar, fox, hare, and golden eagle). Cut-marks found on some caprine, suid, and bovid bones suggest they result from butchery and consumption activities. These findings must be interpreted with caution as Les Bréguières is a funerary deposit and no contemporary dwelling has been found nearby. Moreover, because of the limited field documentation, the original relationship between the animal and the human bones remains poorly understood.

\section{3 | Chronology of the deposit and special features of the site in the regional context}

A first series of 10 direct AMS measurements placed the site's use as of collective burial between the end of the sixth and the beginning of the fifth millennium BCE (Provost et al., 2017). This has shed new light on the variability of funerary practices during the late ImpressoCardial (IC) and Square-Mouthed Pottery culture (SMP) transition. Most of the burials of this period are isolated within domestic or herding sites, generally occurring as single burials or in a few cases as groups of small sets of several individuals (Zemour et al., 2016). Deposits of over 10 individuals are rare, for example, Orco FeglinoArma dell'Aquila in Liguria (Biagi \& Starnini, 2018), Cabrières-Baume Bourbon in Occitania, La Garrotxa-Cova de l'Avellaner in Catalonia, including cannibalized remains from Salernes-Baume Fontbrégoua in Provence and Ambérieu-en-Bugey-grotte du Gardon in Dauphiné (Zemour et al., 2016). In addition, regardless of the number of individuals, the funerary practices are associated with a large variety of subsistence activities at these sites. In this context, the reassessment of the Les Bréguières assemblage shows a contrasting situation, since it indicates that formal cemeteries situated away from habitation sites do exist as early as the IC period. The special configuration of such sites, here in a narrow fault, as well as the scarcity of associated goods, probably explains the low visibility of these locales.

The configuration of the site highlights some biases in the general appraisal of funerary practices and raises the issue of the reliability of palaeodemographic modeling within the Mediterranean Neolithic context (Bocquet-Appel \& Bar-Yosef, 2008). In order to make the chronological range of the funerary occupation more accurate, another set of direct dates were estimated. Finally, 25 samples already selected from 23 human skulls for combined isotopic and paleogenetic studies, and from two animal and one plant remains have been dated; two skulls (BR H20_3236 and BRG H04_3386) were dated twice (SI2). Bayesian modeling was performed through ChronoModel v.2.0.18 (Lanos, Philippe, Lanos, \& Dufresne, 2016) and IntCal.13 curves (Reimer et al., 2013). Out of the 23 dated skulls, 19 have adequate documentation which places these remains within the sequence described by the original field observations. This places the remains between layers $\mathrm{C} 1$ at the top and $\mathrm{C} 8$ at the bottom. For these 19 skulls, as well as for the three animal or plant remains attributed to the archaeological layers, it is possible to apply constraints in a Bayesian perspective (Figure 2). For the remaining four skulls, it appears that all are included in the chronological range given by the stratified ones. Using the modes a posteriori as representations of the beginning (BMAP) and end (EMAP) of the different phases (Binder et al., 2017), the final result (SI2) shows that most of the dated human remains $(24 / 25)$ have been deposited between ca. 5,250 and 4,600 BCE. This range of dates covers distinct cultural episodes without indication of significant gaps. The earliest deposits from phase $\mathrm{C} 8$ _C6 (four individuals) and C5 (seven individuals), from BMAP 5210 to EMAP $4875 \mathrm{BCE}$, postdate the Early Cardial (ca. 5,500-5,250 BCE) period which follows the pioneer Impressa settlements in the Tyrrhenian side (ca. 5,800-5,500 BCE) (Binder, Lanos, 


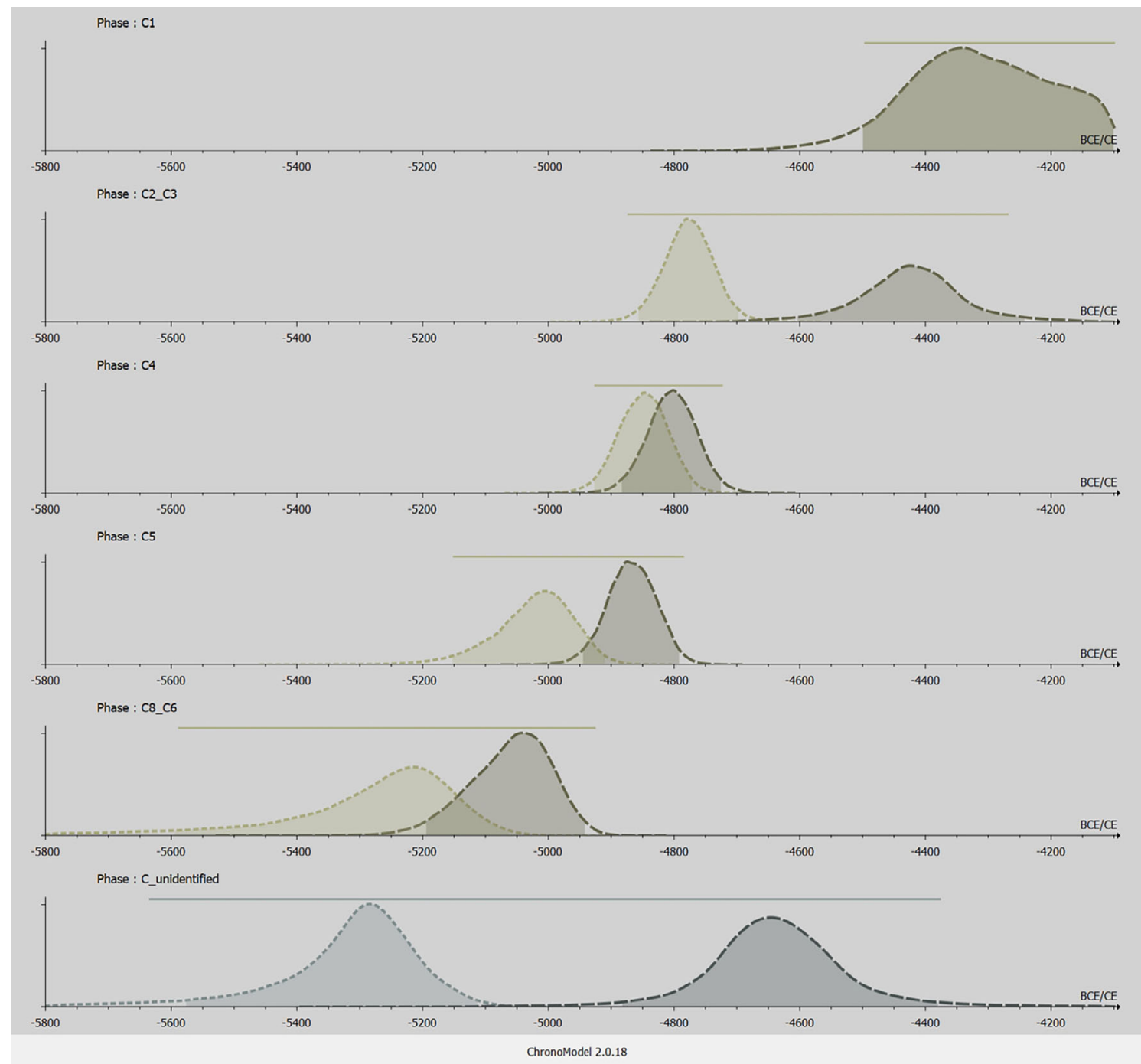

FIGURE 2 Model of phases built for Les Bréguières AMS dates. The constraints are only applied on groups of events with available information on relative stratigraphic position (in brown); the chronological range of samples with unspecified stratigraphic location is colored in gray. Light colors correspond to the density of probability of phase beginnings, darker ones to phase ends

et al., 2017). This corresponds to a period of intense cultural turnover. Indeed, this temporal range includes Classical/Late Cardial mainly in western and central Provence, the earliest aspects of the Pre-Chassey in central Provence and aspects relating to the SMP Transition in eastern Provence and Liguria. The latter are probably under the influence of Neolithic groups from northeastern Italy, that is, Vho and Fiorano (Binder, Battentier, Delhon, \& Sénépart, 2017; Binder, Lepère, \& Maggi, 2008; Starnini, Biagi, \& Mazzucco, 2018). The deposits from phases $\mathrm{C} 4$ (three individuals) and C3_C2 (eight individuals), from BMAP 4850 to EMAP $4430 \mathrm{BCE}$, cover the range of the Early SMP, that is, Finale-Quinzano, in Liguria and a large part of the Pre-Chassey culture (Binder et al., 2008).

\subsection{Sample selection}

Sample preparation is described in detail in SI 1a and 3 to 5.
The multiple burial context is usually not favorable to develop such an approach, but bone selections permitted the investigation of the different issues. The minimum number of individuals of the human collection was established with the femur, determining at least 61 individuals, including 35 adults and 26 pre-adults (Provost et al., 2017). Even if providing the greatest number of individuals, the femur was not included in our sampling selection, as not informative regarding the sex determination and not efficient for aDNA and strontium analyses. Two anatomical elements were thus selected: (a) coxal bone ( $n=17$ ) and (b) skull associated with mandible and/or maxilla $(n=19)$. For coxal bone selection, only remains providing reliable sex determination (>99\%; Murail, Bruzek, Houët, \& Cunha, 2005) were used. This includes eight male and nine females (Provost et al., 2017; SI 1). The internal face of the ilium part was sampled for all coxal bones, by using small Dremel ${ }^{\circledR}$ like saw and cutting device (diam $10 \mathrm{~mm}$ ). Bone chunk is used for CNS stable isotope analysis to discriminate, if applicable, male vs. female diet and mobility. For skull selection, only skulls in 
association with the mandible and/or maxilla were selected. This sample includes 19 adults ( $18+1$ previously sampled in Provost et al., 2017) and 17 immature skulls (SI 1). This sampling procedures permit access to carbon, nitrogen and sulfur stable isotope analysis, petrous bone for aDNA, teeth for calculus microremains study and teeth for ${ }^{87} \mathrm{Sr} /{ }^{86} \mathrm{Sr}$ analysis. Only one individual $(\mathrm{Br} 19)$ provided anatomical elements in connection, which permitted extraction from both cranial and postcranial elements. For the other samples, there remains the risk of duplicating results from the same individual; however, in a first step, coxal and skull samples are independently studied. To complete several animal species (domestic and wild; SI 1) were sampled for bone stable isotope analysis (C, N, S), for tooth enamel ${ }^{87} \mathrm{Sr} /{ }^{86} \mathrm{Sr}$ ratios and for calculus, to provide local environmental baselines.

\section{5 | Methods}

Stable isotope analysis of carbon, nitrogen and sulfur (C, N, S) was performed to infer protein intake during tissue development (Ambrose $\&$ Norr, 1993; Szulc, Seeman, \& Delmas, 2000; Valentin, 2003). Carbon isotope ratios allow discussing the environment in which food items were gathered-hunted and/or cultivated-bred. Nitrogen isotope ratios also allow environmental discrimination and anthropic management of soils, but mainly provide additional information on the trophic level of individuals (more methodological details are available in Bogaard, Heaton, Poulton, \& Merbach, 2007; Hedges \& Reynard, 2007; Herrscher \& Goude, 2015; Richards \& Hedges, 1999; Webb et al., 2017). Sulfur isotope ratios are commonly used as a geographical marker and help differentiate between exploited environments (marine vs. terrestrial vs. freshwater; Nehlich, 2009), if local isotopic baselines are properly provided (Nehlich, 2015; Zazzo, Monahan, Moloney, Green, \& Schmidt, 2011). In inland contexts, the combination of these isotopes in human bone permits identification of food consumption from different ecological areas (Goude \& Fontugne, 2016) and the consumption of freshwater resources (Drucker et al., 2018). These data additionally provide information on the consumption of marine resources and/or the closeness to the sea in coastal areas (Lelli et al., 2012; Virginia \& Delwiche, 1982); foods from estuarine environments can also be detected (Eerkens, Byrd, Spero, \& Fritschi, 2013; Salazar-García et al., 2014).

Dental calculus is oral plaque that has been mineralized by salivadeposited calcium phosphate. This ubiquitous oral disease can often be found on ancient human and animal teeth. Ancient dental calculus is a useful supplement to dietary reconstruction because it can contain embedded dietary information including starch grains, phytoliths, lipids, proteins and DNA from plant and animal foods (Boyadjian et al., 2016; Dobney \& Brothwell, 1986, 1988; Power, Salazar-García, Wittig, \& Henry, 2014; Power et al., 2018; Warinner et al., 2014). Although dental calculus presents a highly stochastic record (Leonard, Vashro, O'Connell, \& Henry, 2015; Power, Salazar-García, Wittig, Freiberg, \& Henry, 2015), it is uniquely valuable because it offers direct information on food consumed and on substances that entered the mouth such as fibers, medicine and even airborne dust (Armitage,
1975; Hardy et al., 2009; Henry \& Piperno, 2008; Leonard et al., 2015; Power et al., 2014, 2015, 2016; Warinner et al., 2014).

For this study, 24 samples of human dental calculus were analyzed, with six samples including faunal dental calculus and archaeological sediment as controls. Each tooth in the study was evaluated and sampled for dental calculus at the CEPAM Laboratory (Nice, France) (SI 4). Most teeth had dental calculus deposits and further description of methods are available in SI 4.

Strontium ( $\mathrm{Sr}$ ) isotope analysis on tooth enamel $(n=56)$ was performed to infer human provenance and territorial mobility (Strauss et al., 2015). The Sr isotope ratio used for this analysis depends on the proportions of ${ }^{87} \mathrm{Sr}$ and ${ }^{86} \mathrm{Sr}$ isotopes found at different geological areas. Strontium enters ecosystems through weathering rocks, through the soil and into the food chain. It eventually gets incorporated into mammal tissues such as enamel by substituting calcium, all with minimal isotopic fractionation (Ericson, 1985; Faure \& Powell, 1972; Graustein, 1989). As living organisms incorporate Sr mainly through food but also water, this means that the $\mathrm{Sr}$ in enamel is ultimately derived from the Sr of the bedrock, soils and water where individuals were living when the teeth were formed (Bentley, 2006). The ${ }^{87} \mathrm{Sr} /{ }^{86} \mathrm{Sr}$ signature of a specific location, which varies between 0.700 and 0.750 on Earth, is determined by the underlying bedrock age and its content of rubidium (Rb). Older geological formations like granite rocks have higher ${ }^{87} \mathrm{Sr} /{ }^{86} \mathrm{Sr}$ values than younger geological formations such as volcanic rock because radiogenic isotope ${ }^{87} \mathrm{Sr}$ forms by radioactive decay from rubidium $\left({ }^{87} \mathrm{Rb}\right)$. Effects such as weathering, hydrological cycles, biopurification and diagenesis will also affect the ultimate bioavailable Sr ratio from a specific location and should consequently be considered when designing the geological sampling strategy and discussing the interpretation (Bentley, 2006; Slovak \& Paytan, 2013).

Tooth enamel, a highly mineralized (96\%) tissue mainly composed of apatite, is the preferred substrate for biogeochemical analysis as it is more resistant to diagenesis from the burial environment than other skeletal tissues (Budd et al., 2000; Hoppe et al., 2003). Because enamel has no turnover during life (Nanci, 2013), an inedible isotopic record of infant and childhood diet is captured in this tissue (Humphrey et al., 2008). Due to the incorporation of bioavailable $\mathrm{Sr}$ values in humans during enamel mineralization, isotopic data can be used to provide information on provenance and territorial mobility based on the idea of matching the isotopic signatures from an individual to the biologically-available signature at a suspected location of origin. Furthermore, it is potentially possible to identify other changes occurring during infancy and childhood such as birth, breastfeeding, and weaning (Humphrey et al., 2008). When studying provenance and territorial mobility it is useful to compare teeth from a same individual that reflect different moments of its life, such as by comparing a $\mathrm{P} 2 / \mathrm{M} 2$ with an $\mathrm{M} 3$ to assess through ${ }^{87} \mathrm{Sr} /{ }^{86} \mathrm{Sr}$ if changes in geological substrate occurred between childhood and early adulthood. Population-wise, the analysis of the ${ }^{87} \mathrm{Sr} /{ }^{86} \mathrm{Sr}$ ratio in tooth enamel from a large number of individuals from a single population can also be useful to tag possible non-locals. In order to be able to retrieve more detailed information on territorial mobility, bioavailable $\mathrm{Sr}$ 
mapping is necessary (Evans, Chenery, \& Montgomery, 2012; Price, Bentley, Lüning, Gronenborn, \& Wahl, 2001), but its elevated cost makes difficult the detailed mapping of bioavailable $\mathrm{Sr}$ in the study region. Sample preparation for $\mathrm{Sr}$ analysis is provided in $\mathrm{SI} 1 \mathrm{a}$.

Finally, ancient DNA (aDNA) analysis was performed to infer maternal vs. paternal diversity in the Les Bréguières group. A total of 30 samples derived from preserved petrous bone were submitted for DNA analyses that targeted uniparental markers, that is, mitochondrial DNA (mtDNA), for the characterization of maternal lineages and $Y$ chromosome for paternal lineages (see details in SI5; Mendisco et al., 2011). Because the human remains were excavated without decontamination methods, bones were systematically decontaminated, that is, scraped, cleaned with bleach and subsequently exposed to UV radiation for 20 min on each side (Boessenkool et al., 2017). All procedure details concerning DNA isolation and mtDNA/Y chromosome SNPs (Single Nucleotide Polymorphisms) analyses are available in Rivollat et al. (2015) and in SI 5. The dataset compiled by Beau et al. (2017) and grouping mitochondrial data available for Mesolithic to Late Neolithic populations (ca. from 14,500 to 2,600 cal. BCE) was used to explore the relationships of the Les Bréguières group with other ancient populations. The dataset was divided into 16 chronological, geographical, and cultural groups for the sake of clarity (see details in Beau et al., 2017). Classical PCA based on haplogroup frequencies was performed in Past version 3.14 software (Hammer, Harper, \& Ryan, 2001) using major European and Near Eastern haplogroups (see Rivollat et al., 2015 for details).

When appropriate, statistic comparisons were performed by using nonparametric tests (Mann-Whitney $U$ test, median test and KruskalWallis test; Statistica $9.1^{\circledR}$ ) due to the small sample size.

\section{3 | RESULTS}

\subsection{Carbon and nitrogen stable isotopes}

Complete datasets are provided in detail in SI $1 \mathrm{~b}$ and 2 to 6.

Animal values indicate different ranges according to the species (Figure 3; SI 1b). Domestic caprine, Bos sp. and Sus sp. data range from -22.0 to $-20.2 \%$ ofor $C(n=11)$, from 4.1 to $6.9 \%$ ofor $N(n=11)$ and from 10.2 to $12.5 \%$ ofor $S(n=7)$. Values recorded for $C$ and $N$ are in the known variability of these species for the period and the region (Goude \& Fontugne, 2016). Sulfur ratios are in the variability of data recorded for prehistoric animal remains located in the Mediterranean and Adriatic areas (Lelli et al., 2012; Varalli, Moggi-Cecchi, Moroni, \& Goude, 2016). Stable isotope ratios for human coxal bones and juvenile skulls range from -20.1 to $-18.1 \%$ for $C\left(\Delta^{13} \mathrm{C} 2 \%\right.$; $\left.n=34\right)$, from 8.9 to $11.1 \%$ o for $\mathrm{N}\left(\Delta^{15} \mathrm{~N} 2.2 \%\right.$; $\left.n=34\right)$ and from 6.4 to $14.6 \%$ for $\mathrm{S}\left(\Delta^{34} \mathrm{~S} 8.2 \%\right.$; $n=33$ ). Stable isotope ratios for human adult skulls range from -20.3 to $-18.9 \%$ of $C\left(\Delta^{13} \mathrm{C} 1.4 \%\right.$; $\left.n=19\right)$, from 9.0 to $10.9 \%$ for $\mathrm{N}\left(\Delta^{15} \mathrm{~N} 1.9 \%\right.$; $\left.n=19\right)$, and from 9.3 to $15.0 \%$ ofor $\mathrm{S}\left(\Delta^{34} \mathrm{~S}\right.$ $5.7 \% ; n=18$ ). The mean difference between animal species (caprine, Bos sp., Sus sp. and deer) and human coxal, as well as juvenile samples, is $0.9 \%$ or $\mathrm{C}$ and $4.3 \%$ or $\mathrm{N}$ (Figure 4 ).

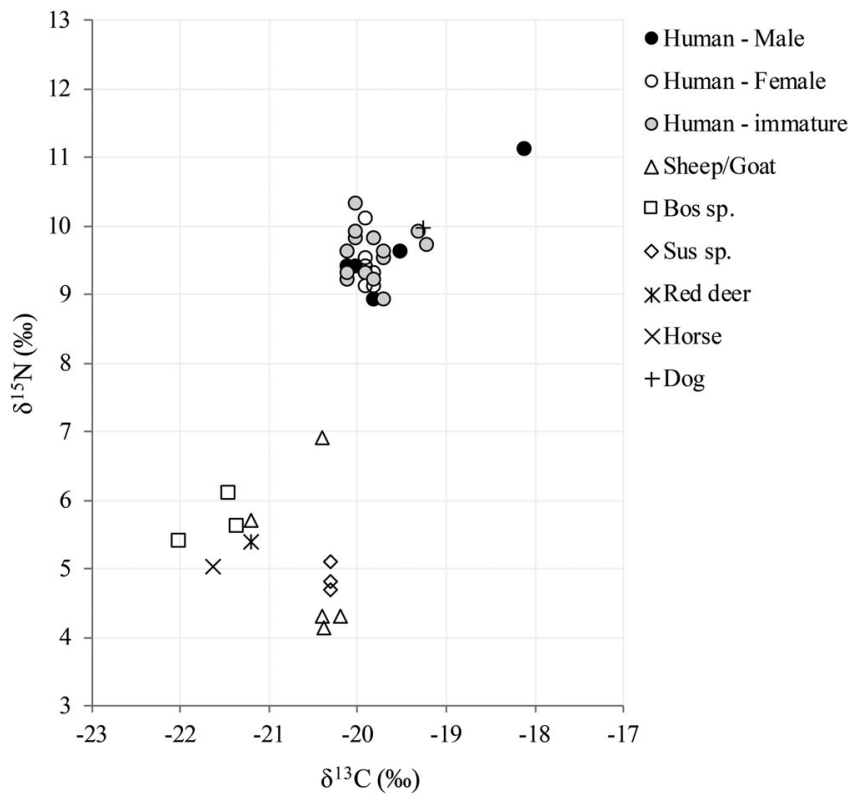

FIGURE 3 Stable isotope ratios $(\mathrm{CN})$ of animals and human female and male adult coxal bones and juvenile skulls

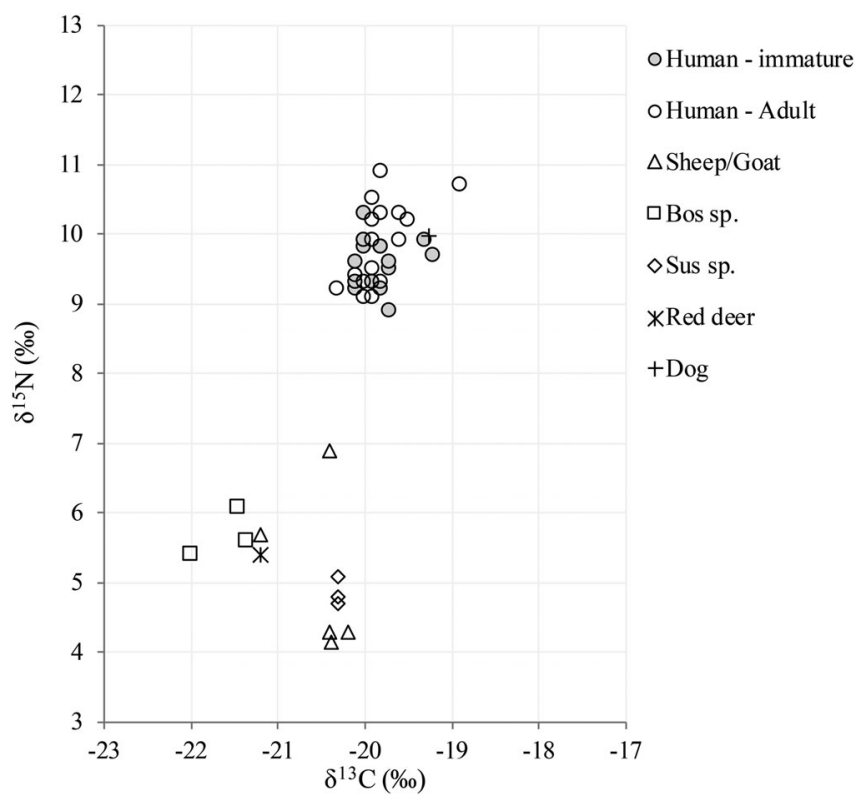

FIGURE 4 Stable isotope ratios (CN) of animals and human adult and juvenile skulls

Sulfur data for animals and human bones are presented in Figure 5, as well as combined with published prehistoric regional data in Figure 6 (Lelli et al., 2012; Varalli et al., 2016). The local range was established by using available animal values for the site (caprine, Sus sp. and deer). Humans exhibit different ranges. Except for two females $(\mathrm{Br} 3723, \mathrm{Br} 3696)$, the rest of the coxal bone values fall within the local range as do most of the juvenile skull values.

The adult skulls $\mathrm{S}$ isotope ratios present two distinct groups, with four individuals within the range of the values from coxal bones and 


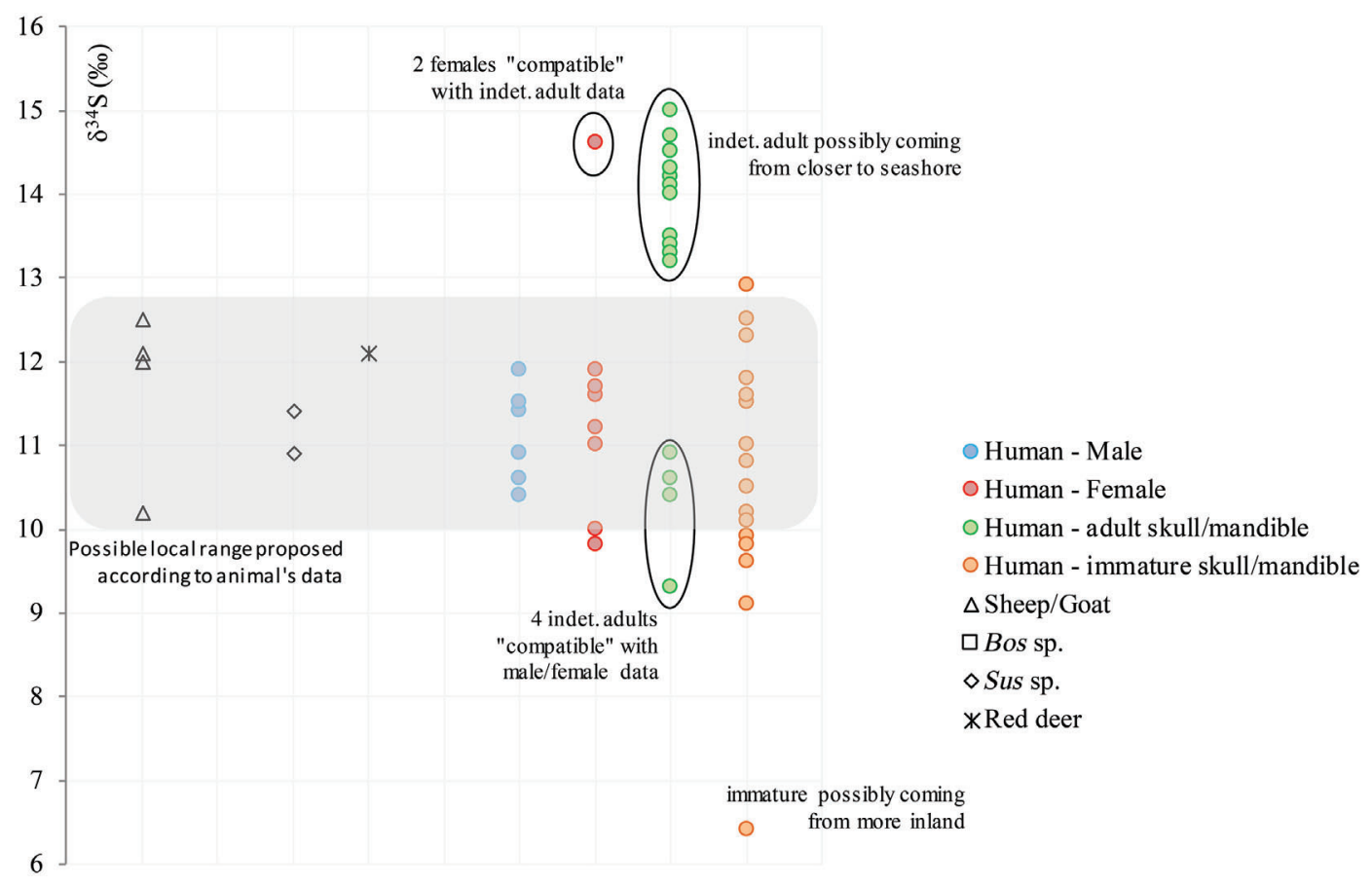

FIGURE 5 Sulfur stable isotope ratios of animals, human female and male adult coxal bones and human adult and juvenile skulls

juvenile samples, while the rest of the individuals have higher $\mathrm{S}$ ratios. Adult and juvenile skulls significantly differed $(p<.01$; Mann-Whitney $U$ test); juveniles providing lowest $\delta^{34} S$ compared to adults. On this basis, it is possible to have individual compatibility between four adult skulls and the coxal bones and between two female coxal bones and the rest of the adult skulls. In such a context, and assuming there is no significant difference in bone turnover between the two anatomical structures (thus not marking different life periods; Fahy, Deter, Pitfield, Miszkiewicz, \& Mahoney, 2017), a second step of the analysis explored isotope data by group and then by excluding the potential compatible samples: (a) 15 coxal bones (i.e., excluding the 2 females $\mathrm{Br} 3723$ and $\mathrm{Br} 3696$ with higher $\mathrm{S}$ values possibly belonging to the individuals represented by the skulls also with higher $S$ values), (b) 17 juvenile skulls, and (c) 14 adult skulls (i.e., excluding the three skulls with lowest $\mathrm{S}$ values potentially compatible with coxal bone data, the duplicate of $\mathrm{Br} \mathrm{H} 19 \_0019$, and $\mathrm{Br} \mathrm{H03} 3386$ bis with no S data). The comparison between the three groups (representing ca. $88 \%$ of the initial sampling) indicates a significant difference in $\mathrm{N}$ and $\mathrm{S}$ isotopic ratios. This difference is still observable when comparing only the adult samples (coxal bone vs. skull) and when comparing the juvenile to the adult skulls for $S(p<.01$; Mann-Whitney $U$ test).

\section{2 | Dental calculus microremains}

Plant consumption was identified in dental calculus from 15 individuals sampled (Figure 7). Samples of the exterior calculus taken from the decalcification rinses produced infrequent microremains. However, one rinse produced several hundreds of fungal spores. In three of the four samples, microremains were rarer than in the inner sample, except in H22_4239 which was an unusually low-mass sample. Across the samples, low numbers of starch and phytolith microremains were recovered (Figure 7; SI 4). Starch grains belong to five types, including one consistent with Triticeae, a hard endosperm starch producing seed (Figure 7). Grass phytoliths closely follow the morphology of grass cells and are readily identifiable using Twiss's conventional guide for grasses, in contrast to phytoliths from dicotyledons (woody herbaceous or arboreal plants), which have irregular forms (Albert, Weiner, Bar-Yosef, \& Meignen, 2000). These phytoliths were identified with the help of a variety of sources (Metcalfe $\&$ Chalk, 1950; Pearsall \& Dinan, 1992; Piperno, 2006; Twiss, Suess, \& Smith, 1969). The monocot types of phytoliths that were found included long-cell elongates, parallelepiped and trichomes. These species are indicative of grasses but undiagnostic of the type of grass or distinctions between domesticates or wild grasses. However, 13 short-cells including seven rondels deriving from pooid grasses and two bilobates from panicoid grasses were found. Grass types were identified in nine of the human dental calculus samples, while just six individuals show dicot types (H09_3356, H16_3252, H31_3218 and H29_3240). These included plate, jigsaw, globular rugulate/echinate, and other phytolith morphotypes indicative of dicots (Metcalfe \& Chalk, 1950; Pearsall \& Dinan, 1992). A variety of other microremains were found in small numbers, including unsilicified plant tissues from monocots, dicots and a conifer, calcium oxalates deriving from a plant, benthic (a shallow water type) diatom, fungal spores, mammal hairs, a feather fragment and microcharcoals.

\section{3 $\quad$ Strontium isotope ratios}

All Sr isotope data generated in this study is in SI 3. The concentration of $\mathrm{Sr}$ from all archaeological samples (both human and faunal) is 
FIGURE 6 Sulfur stable isotope ratios of the Les Bréguières samples compared with other Prehistoric data in the Mediterranean

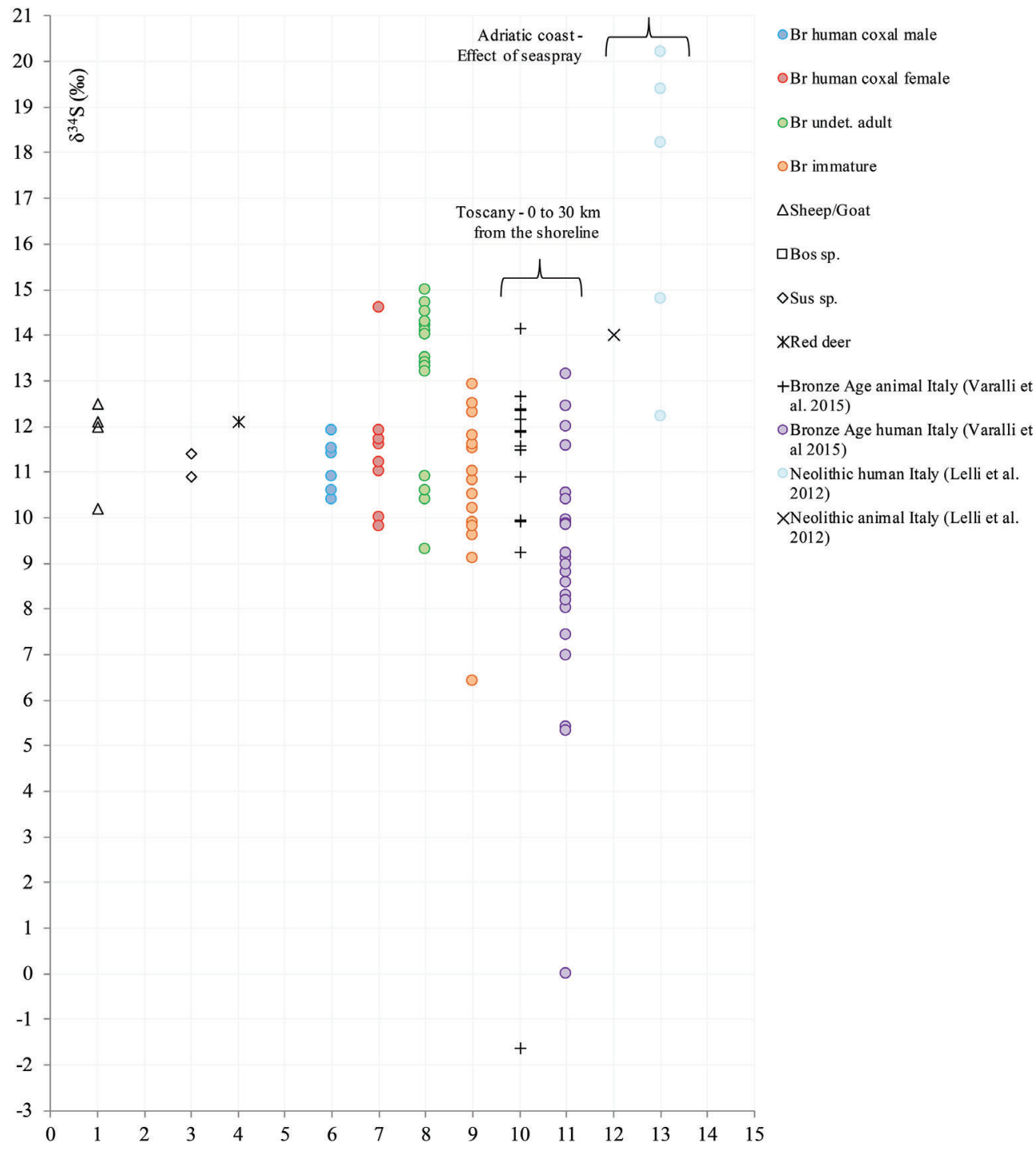

consistent and therefore points to taphonomic robustness of the enamel and discards confounding traceable diagenesis. Background data to define the local bioavailable $\mathrm{Sr}$ and with which to compare the human values studied have been obtained from both the IRHUM database (Willmes et al., 2014) and meso- and micro-fauna analyzed from the immediate surroundings of the site itself (Figure 8). Data from the fauna (European hare and hedgehog; $n=7$ ) range between 0.7087 and 0.7096 , showing only slightly higher values than topsoil and grass samples recorded in a nearby area (8 km north from the site) for which data are available in the IRHUM database (Willmes et al., 2014). All human enamel values range from 0.7081 to $0.7102(n=32)$. Except for one individual, H32_3260-which belongs to the earliest deposits all human data plot within the defined local range (Figure 8). Furthermore, for those individuals from whom two different dental pieces were analyzed, almost no difference is observed between the different stages of the life cycle. The ${ }^{87} \mathrm{Sr} /{ }^{86} \mathrm{Sr}$ values of individual H32_3260 are only slightly higher than those of the local range obtained from fauna, topsoil and plants from the surrounding area of the site: values of 0.710187 (M2) and 0.709979 (M3). When calculating the mean of all human sample $\mathrm{Sr}$ isotope values from the population
$(0.708812 \pm 0.000988 ; 2 \sigma)$, both values still plot outside of the local range (0.707823-0.709800). Notwithstanding, given the current archaeological and anthropological elements available, this potential non-local individual does not present any further particulars to discuss.

\subsection{Ancient DNA data}

The aDNA analyses (SI 5) and the chronological modeling of mtDNA lineages distribution (SI2) provided additional elements for discussion concerning the Les Bréguières group composition. From the 30 analyzed individuals (represented by petrous bones), complete and repeatable mitochondrial SNP profiles could be obtained for 20 individuals (66.6\% success rate), permitting the characterization of eight different maternal lineages (haplogroups) for the Les Bréguières population (Table SNPs SI 5). Unfortunately, no samples yielded reproducible $Y$ chromosome SNPs, preventing any paternal lineage characterization. Complete and authenticated HVS-I sequences proved difficult to obtain in most of the human remains analyzed. Such a classical 


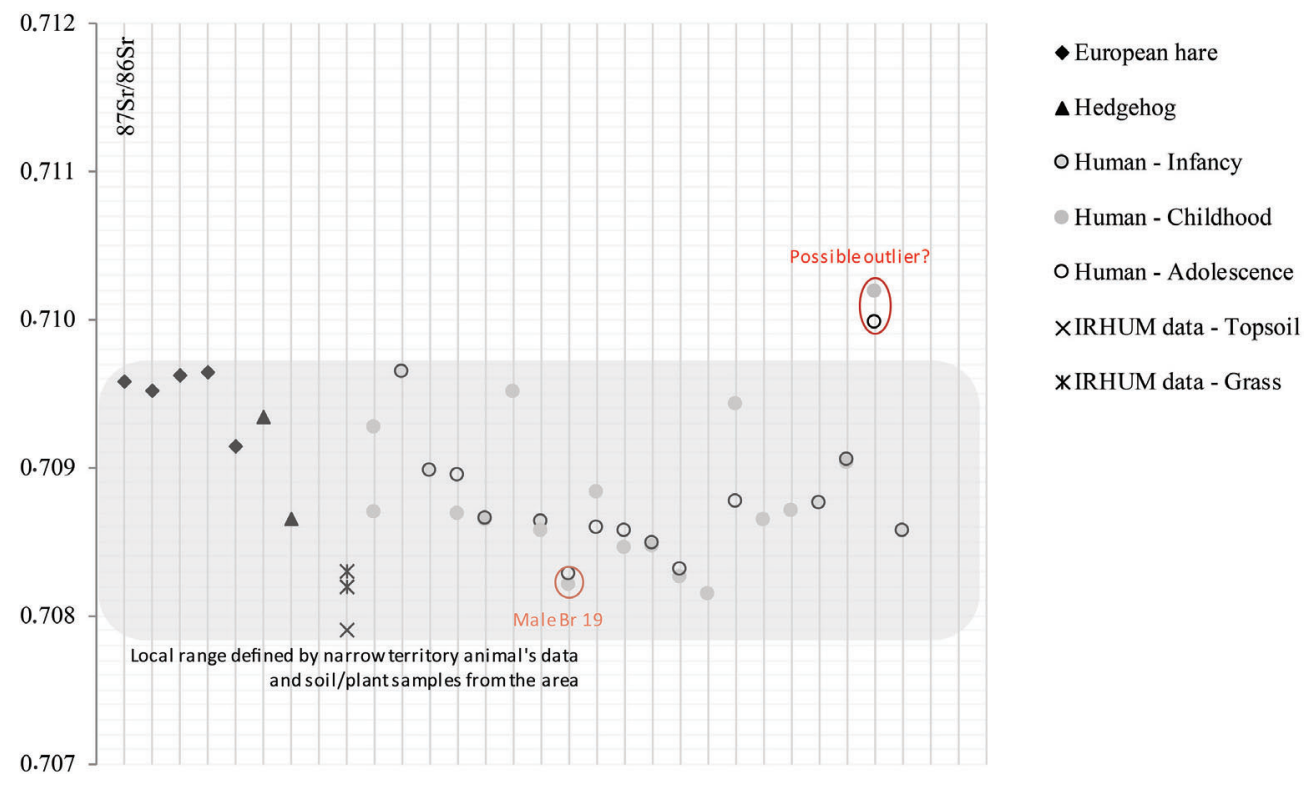

FIGURE 7 Stable isotope ratios $(\mathrm{CN})$ of animals and selected human samples from Les Bréguières compared with Gravettian and Neolithic data in Liguria and Provence. Fish data are from Pouydebat (1997), Lightfoot, Boneva, Miracle, Šlaus, and O'Connell (2011), and Salazar-García et al. (2014). Provence and Ligurian Neolithic data are from Goude et al. (2011-2013)

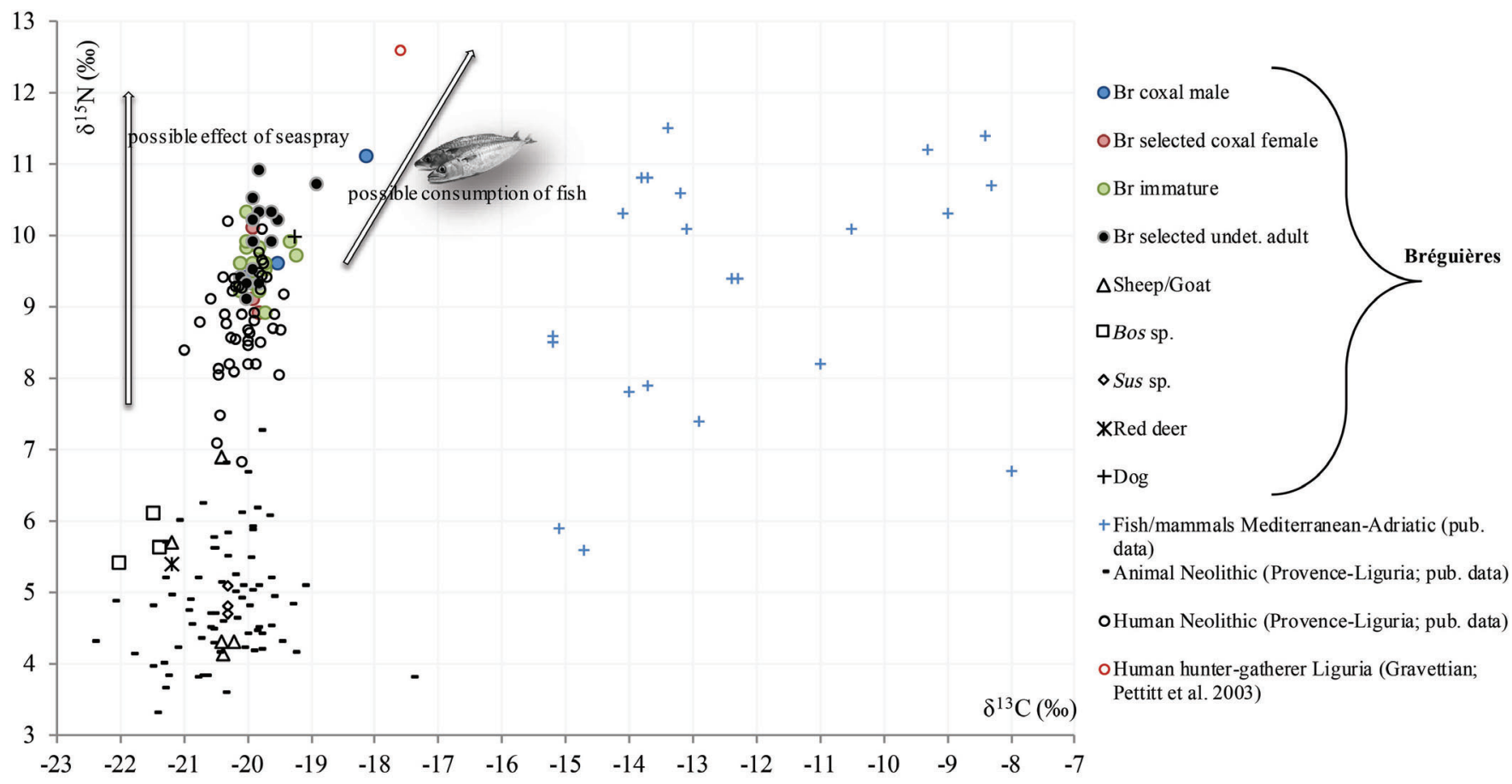

FIGURE 8 Dietary results from Le Vigneau and Les Bréguières dental calculus samples (Goude et al., 2019) and pictures of two different species of plants found in calculus remains. Recovered microremains from dental calculus. (a) Triticeae starch in brightfield light, (b) same starch in polarized light, (c) unsilicified grass cells, (d) microcharcoal, (e) mammal hair, and (f) plant fiber

palaeogenetic approach was, therefore, abandoned. Consequently, all analyses presented here were based on mitochondrial haplogroup (lineage) diversity. A significant diversity of maternal lineages characterized the group of Les Bréguières, including $\mathrm{H} 1, \mathrm{H} 3$, $\mathrm{HV}, \mathrm{J}, \mathrm{J1}, \mathrm{K}, \mathrm{T}$, and U5 lineages. The PCA based on aDNA haplogroup frequencies compiled for ancient European groups (see SI5 for details of the groups) showed that the maternal diversity of the Les Bréguières community (BRE) fits well with the known ancient European Neolithic population diversity (clearly distinguished from ancient hunter-gatherer groups; SI5). Moreover, it is 

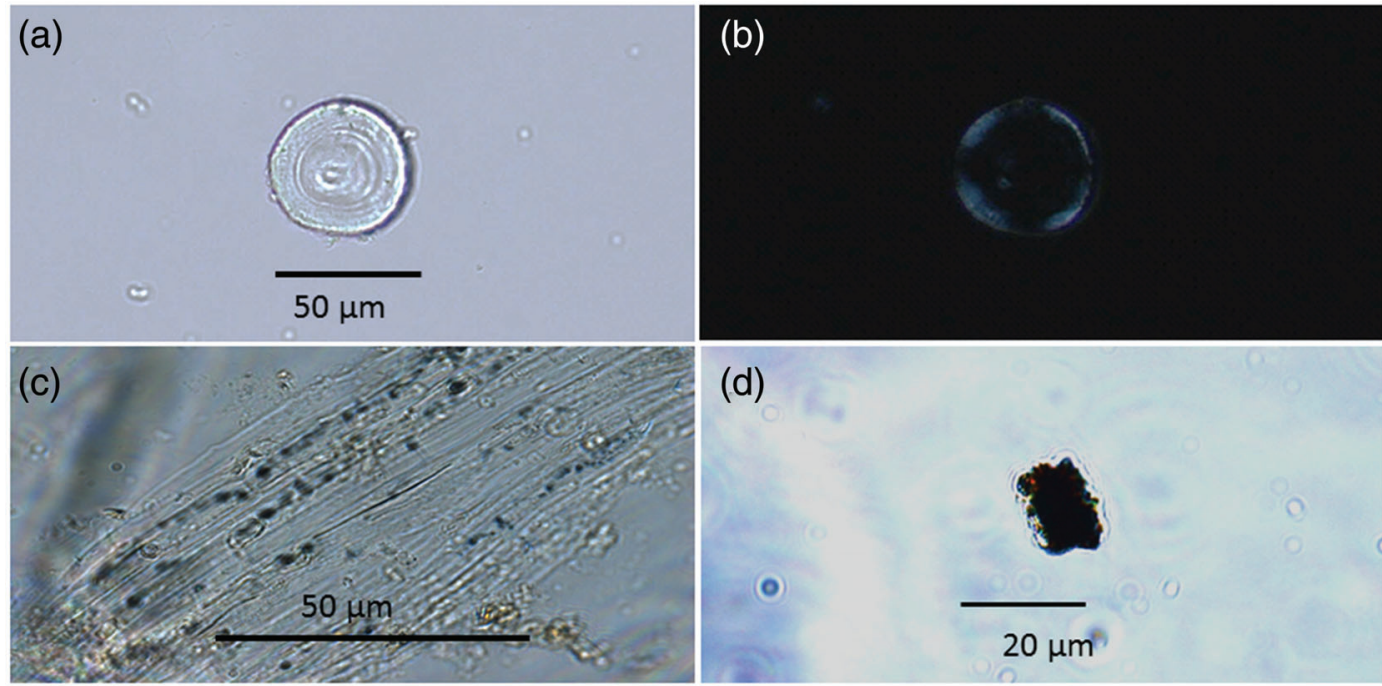

(d)
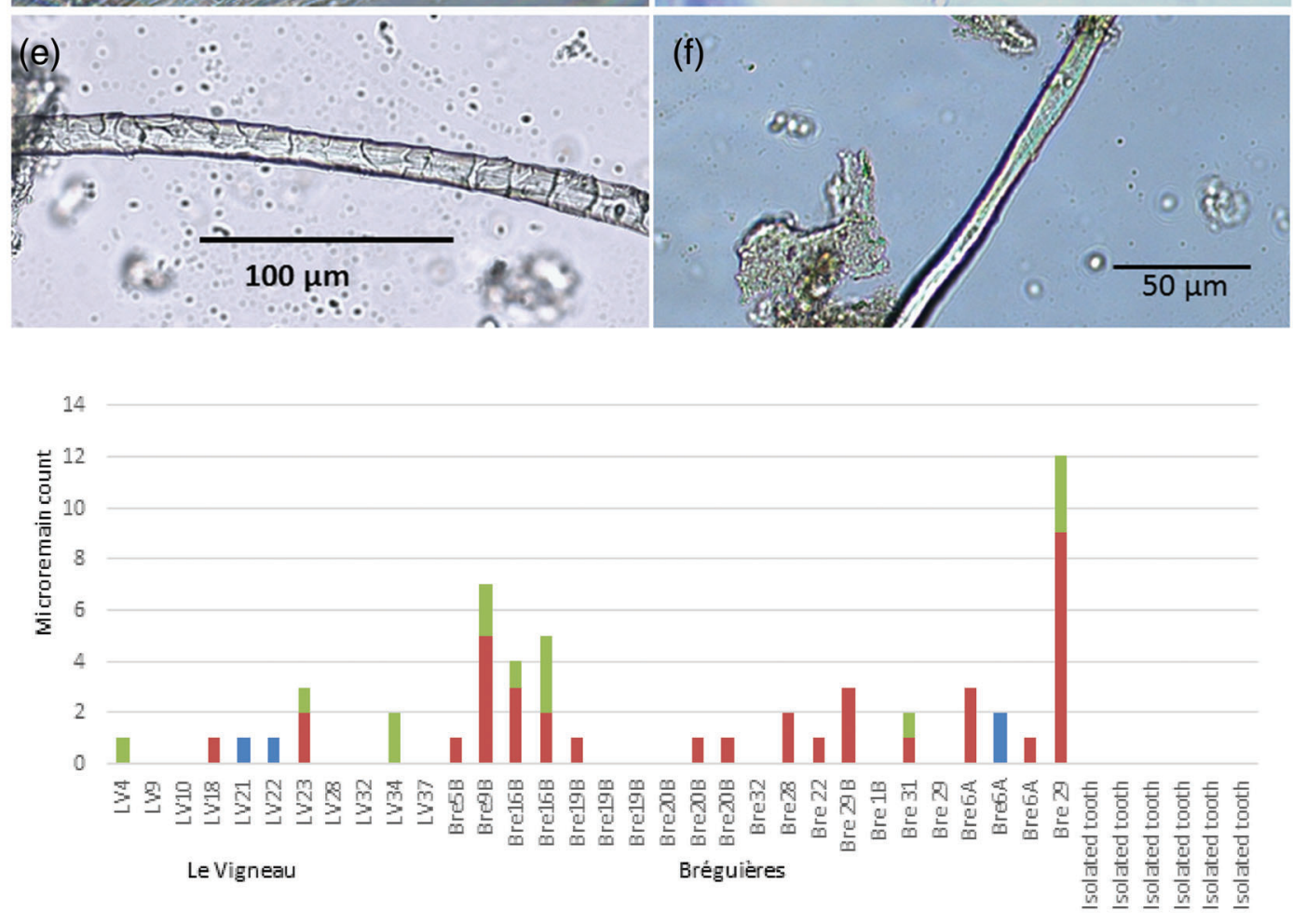

- Total grass starch (Lik ley cereal use) a Total grass phytoliths (likely cereal use) = Total dicot phytoliths (non cereal use)

FIGURE 9 Strontium isotope ratios from animal and human enamel samples and from IRHUM database modern samples

worth noting that the population of Les Bréguières stands in an intermediate position between groups composed of Early Neolithic farmers from Central Europe and those from the Iberian Peninsula. This position is linked to (a) the frequencies of lineages HV (5.26\%) and $\mathrm{J}(10.53 \%)$ in the BRE group which are close to those in Central European Neolithic groups (LBKT and LBK), (b) the low frequency of lineage $T$ (5.2\%) which is closer to the frequency found in Cardial groups from Iberia (CRD), and (c) the noticeable frequency of lineage U5 (typical hunter-gatherer lineage; 10.53\%) that drives the BRE group closer to Middle/Late Neolithic groups from France (MNF, MICH), Central Europe (BEC), or Iberia (LNS).

\section{4 | DISCUSSION}

\section{1 | Terrestrial versus marine environment exploitation}

Isotopic data from all the coxal bone and juvenile skull compared with potential consumed animal species (caprine, Bos sp., Sus sp. and deer) indicate elevated reliance on terrestrial animal protein, as is often observed during the Neolithic in eastern Provence and Liguria (Goude et al., 2011-2013). However, one male ( $\mathrm{Br}$ 3515) presents data consistent with the consumption of different proteins, probably marine 
resources (France, 1994; Schoeninger \& De Niro, 1983). The correlation between $\mathrm{C}, \mathrm{N}$, and $\mathrm{S}$ isotopic values was not examinated of all the coxal bones. Thus, the hypothesis of a diet turned toward marine resources is not favored to explain the specific $\delta^{34} S$ recorded in two female coxal bones (Figure 5). This data suggests these two women lived in a different place, perhaps more exposed to the sea spray effect, a factor known to add marine enriched $\mathrm{S}$ in soils, which is then reproduced in primary producers (Zazzo et al., 2011). Few juveniles (ca. one third of the immatures), and more particularly $\mathrm{Br} 3256$ bis, present low $\mathrm{S}$ values, compatible with a more inland geographical origin (Figure 5).

CNS bone data were secondly considered along three new groupings excluding the potential compatible samples. The $\mathrm{N}$ and $\mathrm{S}$ isotopic ratio differences recorded could be due to different bone turnover, life phases, and or element uptake for each of the three identified groups, each represented by a different anatomical element. This result leads to questions about the geographical origins and the use of the funerary space between 5,250 and 4,600 BCE. Different dietary patterns and/or the exploitation of different ecological habitats emerge, particularly for individuals represented by adult skulls (Figure 9). Some of these individuals show high $\mathrm{N}$ and $\mathrm{S}$ values (see SI1, individuals with $\delta^{34} \mathrm{~S}>13.0 \%$ ) which are compatible with either the sea spray effect (Virginia \& Delwiche, 1982) and/or consumption of ${ }^{15} \mathrm{~N} /{ }^{34} \mathrm{~S}$ enriched resources (possibly marine foods). This pattern seems slightly different to that of the male individual previously highlighted as having high $\mathrm{C}$ and $\mathrm{N}$ isotopic ratios ( $\mathrm{Br}$ 3515). A comparison with other prehistoric human groups and coeval animal remains from eastern Provence and Liguria strengthens the specific trophic position of some of the Les Bréguières individuals (Figure 9; Pettitt, Richards, Maggi, \& Formicola, 2003; Le Bras-Goude et al., 2006; Le Bras-Goude, Binder, Simon, \& Richards, 2006; Le BrasGoude, Binder, Zemour, \& Richards, 2010; Müller, Le Bras-Goude, Buscaglia, \& Reiche, 2009; Goude et al., 2011-2013). When the pattern is compared to that of an Upper Paleolithic individual and considering the wide range of values of marine fish and mammals in the Mediterranean and Adriatic (Garcia-Guixé, Subirà, Marlasca, \& Richards, 2010; Lightfoot et al., 2011; Pouydebat, 1997; SalazarGarcía et al., 2014), the consumption of marine food appears as a suitable hypothesis to explain the outlier individuals, in particular the male $\mathrm{Br} 3515$ and $\mathrm{Br}$ H28_3220. For the other individuals, dietary habits are not evident as carbon isotope ratios do not correlate with a $\mathrm{N}$ and $\mathrm{S}$ increase. The comparison between the animal data (caprine, Bos sp., Sus sp. and cervid) of Les Bréguières and other Liguro-provençal areas does not show a statistical difference; however, the same comparison for humans indicates a significant difference (excl. Outlier $\mathrm{Br}$ individuals) for both $\mathrm{C}$ and $\mathrm{N}$. Even if significant, the difference recorded is small $(+0.1 \%$ of $\mathrm{C}+0.8 \%$ of $\mathrm{N}$, in favor of the Les Bréguières individuals) which could be explained by different geographical origins and the influence of the sea spray effect on the data.

For further discussion, local marine resource datasets are needed, which for the moment are unavailable. Previous analyses in the area (Early and Middle Neolithic; review in Goude \& Fontugne, 2016) confirmed a subsistence economy turned toward terrestrial resources.
However, most of these sites are at a higher altitude than Les Bréguières. The new data from Les Bréguières bring to light, for the first time, a diversity in protein intake, including the general trend observed among local Neolithic human groups (consumption of terrestrial resources) and the peculiarity of two (or more?) individuals consuming marine foods. This result raises the question of the origin and social status of the buried individuals and the potential link with food consumption. Indeed, if only very few isotopic data indicate significant marine protein intake in coastal early farming communities so far, this could reflect purposeful burial for specialized individuals within caves around this region. The funerary distinctiveness of Les Bréguières (a collective burial) could be considered a mark of a "less selective" place, used by several generations with possibly different origins and cultural traditions.

Contrary to what is shown by the $S$ isotope data, the apparent homogeneity of the $\mathrm{Sr}$ isotope values suggests that the Les Bréguières individuals sampled portray relatively low or non-existent territorial mobility (or an intralife mobility which is not visible through teeth $\mathrm{Sr}$ data). This contrasts with the main trend observed through the $\mathrm{S}$ stable isotope analysis. These findings suggest that $\mathrm{S}$ values observed could reflect diet instead of mobility, and in this case, foods could have traveled through a trading network instead of migratory practices. In any case, and as is usual in this type of approach, the lack of a detailed bioavailable mapping of the broader region limits interpretation. It is also possible that individuals with Sr values compatible with those of the area surrounding the burial migrated from regions with geological features and strontium values. Accordingly, the dataset would simply reflect the ${ }^{87} \mathrm{Sr} /{ }^{86} \mathrm{Sr}$ homogeneity of a larger territory.

\section{2 | Evidence for plant consumption diversity by Neolithic people}

With the exception of those from isolated teeth, the assemblages of microremains from Les Bréguières are suggestive of diets with a significant contribution of cereal plant foods. There is also evidence of leafy dicot plants in the diets. Pooid grasses, such as wheat or barley, seem to have been predominant but phytoliths from panicoids were also recovered. Panicoid phytoliths have previously been found in early Neolithic sediments at CastellarPendimoun, a few $\mathrm{km}$ to the east (Delhon, Binder, Verdin, \& Mazuy, 2020). This study could only find three taxa (all wild) that may have contributed such as phytoliths including Setaria spp., Digitaria sanguinalis or Echinochloa crus-galli. Such wild species may have been collected at Les Bréguières either intentionally for consumption or accidentally during harvesting of crop fields. Unfortunately, preservation is low for these highly diagnostic types, such as multicell husk phytoliths.

The archaeobotanical dataset available for the Early Neolithic in Provence is still limited but information on cultivated and collected wild plants has been gathered from several sites. It is well known that Neolithic farmers of the late IC of Southern France favored naked wheat (Triticum aestivum/turgidum) and naked barley (Hordeum vulgare var. nudum) (Marinval, 1993), while glume wheats, 
emmer (T. dicoccum) and einkorn (T. monococcum), were also emphasized, especially at the beginning of the Neolithic (Binder et al., 2020; Bouby, Durand, Rousselet, \& Manen, 2018; De Vareilles et al., 2020). The predominance of naked cereals in several sites from the end of the sixth mill. BCE could possibly explain the underrepresentation of multicell husk phytoliths, as glumes of naked cereals are easily eliminated by simple threshing, often immediately after the harvest. This explanation could also be offered at Le Vigneau as naked cereals were favored in the whole Chassey culture area until ca. 4,000 BCE (Martin et al., 2016). Alternatively, the under-representation of husk phytoliths could be explained by (a) the thorough processing of any kind of cereal and by removing most of the husk and (b) the poor preservation of these phytoliths due to local alkaline soil conditions.

\section{3 | The diversity of plants consumed may be linked to human mobility}

Although there is not a wide variety of datasets to compare with, the Les Bréguières results are relatively richer than those from Le Vigneau (Goude et al., 2019). This could possibly reflect a more diversified diet at Les Bréguières regarding plant foods. It is especially true regarding the four individuals (H09_3356, H16_3252, H29_3240, H31_3218), who yielded the most diversified content in microremains, including phytolith evidence for the consumption of eudicotyledon plant products. It is worth mentioning that these individuals are adults presenting high $\delta^{34} \mathrm{~S}$ values (SI $1 \mathrm{~b}$ and 4 ), potentially coming from other places, maybe closer to the seashore, compared with the other individuals. Cultivated eudicotyledons are rather scarce in the archaeobotanical record. From a global point of view, carbonization favors the preservation of cereal remains compared with most of the dicotyledons; cereal processing can involve heating at different steps and caryopses preserve well when charred. Eudicotyledons are therefore often under-represented in charred archaeobotanical assemblages. Pulses have been occasionally encountered in Cardial sites from Provence (end of the sixth mill.), at la Font-aux-Pigeons (Châteauneuf-les-Martigues; Marinval, 1988) and la Baume Fontbrégoua (Savard, 2000). Various wild eudicotyledon fruits and seeds were also probably eaten by Neolithic populations. Fruit remains were found at several Cardial sites in Provence, especially acorns (Quercus sp.) at Pendimoun, Grotte Lombard, Vieux Mounoï and Fontbrégoua, as well as several other tree and shrub species in this last site. Additionally, many wild resources, such as leaves, bulbs, roots, seeds from herbaceous plants, were also likely gathered but, due to preservation problems, can only be identified in rare favorable conditions (Behre, 2008). Wild resources probably represented an important proportion of the eudicotyledons consumed by Neolithic people, but barely left any trace in most sites. The diversity of biotopes all rich in eudicotyledon plants, accessible at a short distance from Les Bréguières, from the seashore to mountain environments, probably favored the use of a high diversity of food resources. These results provide the first evidence that the groups of Les Bréguières consumed a wide breadth of plant foods that required access to diverse environments.

\subsection{A social organization potentially ruled by a patrilocality system}

The mitochondrial data obtained for the Les Bréguières group highlighted a maternal pool that fits well with the known ancient European Neolithic population diversity (clearly distinguished from ancient hunter-gatherer groups; SI5) and that stands in an intermediate position between groups composed of Early Neolithic farmers from Central Europe and the Iberian Peninsula. This intermediate position, between the more ancient and the contemporary farming groups associated with distinct neolithization migratory waves, raises questions of surrounding genetic affiliations between individuals at Les Bréguières and Neolithic migrations (Rivollat et al., 2015). The low sample size recovered from the Les Bréguières group and the current lack of genetic data for other Early/Middle Neolithic groups from southern France (or even Italy), however prevents any further interpretation. The noticeable mitochondrial diversity measured in the Les Bréguières group has been regularly observed in Neolithic farming groups (Lacan et al., 2011; Szécsényi-Nagy et al., 2015) and could be an indicator of a patrilocal residence rule. Evidently, $Y$ chromosome data are necessary to directly test this hypothesis. Nevertheless, given the important chronological distribution of the individuals (over more than 30 generations), a more parsimonious but not exclusive explanation would be the use of the funerary site by maternally differentiated groups. This suggestion finds a notable echo in their dietary diversity at the site. Whatever the explanation, the Sr data indicate that individuals share homogenous $\mathrm{Sr}$ values compatible with those measured for the area surrounding the cave. That would mean (a) that, in the case of patrilocality, the females originated from geographically close communities and (b) that, with regards to the use of the funerary site by different groups, these groups originated from the same local territory. Through chronological modeling of mtDNA haplogroups an analysis of their distribution through time, that is, during the use of the burial, can be conducted (Figure SI2).

The individuals with haplogroups $\mathrm{K}$ and $\mathrm{H} 1$, which are better represented, respectively with seven and four individuals, can be observed throughout the site's use, from ca. 5,160 to ca. 4,600 BCE (i.e., Late Cardial/Vho group and Early SMP), potentially indicating genetic continuity over time (Tables SI2). For the remaining mtDNA lineages, the number of individuals is unfortunately too small to discuss chronological distribution. For U5 and J1, which could appear even earlier than $\mathrm{K}$ and $\mathrm{H} 1$, stratigraphic constraints are lacking for half of the individuals, a fact that could explain the wider spread of probability densities. Only the $T$ individual could have post-dated the others. No clear association could be observed between a specific period of use of the burial and maternal lineages. Nevertheless, the specific presence of lineages $\mathrm{K}$ and $\mathrm{H} 1$ (five and three individuals respectively) among clusters $\mathrm{C} 2-\mathrm{C} 4$, that is, between 4,840 and 
4,650 BCE has to be pointed out. The maternal homogeneity encountered for this short period could correspond to individuals tied by kinship, being buried together. Finally, when comparing mitochondrial haplogroups to both groups determined by $\mathrm{S}$ isotopic ratio as (a) falling within the local range and (b) under the influence of the seashore, it appears that each group has its own distribution of mitochondrial profiles, except for K, a typical Neolithic haplogroup, which is present in both groups. For unique haplogroups, this does not reveal any pattern. However, a pattern appears for $\mathrm{H} 1(n=4)$ and $\mathrm{U} 5(n=2)$ which are both in the group with a local signal. This could suggest an internal biological structure of the Les Bréguières group with two different dietary behaviors, which needs to be investigated in the near future. In sum, palaeogenetic results for the Les Bréguières group are only preliminary and future genome-wide analyses are necessary to provide more information on community composition and origin, residence rules or even diet/health questions that are documented through isotope analyses.

\section{5 | New insight on Mediterranean Neolithic behaviors}

This study has demonstrated that question-driven sampling strategies for multiproxy methodologies can provide meaningful data from old and poorly documented osteological collections. The sampling and methodological strategies allowed documenting the objectives of the research. First, the necessary evidence to reevaluate the explanation on early farming diets was collected. The results demonstrate that the diversity of food resources consumed was probably related to the richness of local Mediterranean biodiversity. On the one hand, marine proteins were significant for certain individuals, supporting a reevaluation of the previously proposed patterns for dietary transition in Western Europe during neolithization. On the other hand, plants recovered in dental calculi demonstrated the use of domesticated species, such as barley and wheat, as well as some wild species, for example panicoids. However, for this last category, the input could be due to either food or contamination from the environment.

Secondly, this work provided new information on social organization. The funerary space at Les Bréguières was used by local and/or sublocal human groups during mainly four centuries. The hypothesis of a use by nonlocal people could be strengthened both by (a) the $S$ stable isotope results that allow discrimination of individuals who originate from locations exposed to different environmental influences, such as sea spray, and (b) the noticeable maternal diversity measured for the Les Bréguières group. However, intra- and inter-individual $\mathrm{Sr}$ isotopic results do not provide evidence for high territorial mobility.

Finally, despite the difficulties due to the sample bias (the material only comes from a collective burial) the issue of female versus male behaviors was revealed. This new study provides some elements about the question of female versus male behaviors within the early farmer communities. No clear sex-related dietary/mobility pattern is evidenced, but it is worth reminding that, among coxal bones studied, marine protein intake was recorded only in a male individual and specific sulfur isotope ratios were recorded only in female individuals. While some Neolithic human groups demonstrate gender-based protein intake (e.g., in the Paris Basin (Rey et al., 2019): females consumed different animal proteins; or Auvergne (Goude et al., 2013): wider variability of resources consumed by women), Mediterranean groups studied until now (this study; i.e., Salazar-García et al., 2018) do not show clear difference between male and female. However, gender-related mobility pattern seems to be a more common observation in many European places. Strontium data in northeastern France and central Europe already demonstrated a wider mobility operated by females (Bentley et al., 2012) and first aDNA mitochondrial results support this social organization mode (Rivollat et al., 2015). Result from this study also support this social organization through preliminary analysis of aDNA data and potentially also with $\mathrm{S}$ isotope ratios, which look to be a more efficient tool compared to $\mathrm{Sr}$ in this Mediterranean area. These new palaeogenomic data should increase the number of individuals for sex determination and allow for a discussion of male versus female behaviors. Finally, this transdisciplinary research paves the way for new perspectives, particularly the potential for novel research on remains excavated near shorelines, including newly excavated assemblages or those curated in museums.

\section{ACKNOWLEDGMENTS}

This research was funded by Institut Danone France/Fondation pour la Recherche Médicale 2015 partnership (Women and diet at the beginning of farming, fifth-third millennium BC, France: a bioanthropological approach; Dir. G. Goude 2016-2017; http:// institutdanone.org/nos-prix/femmes-alimentation-les-premieres-societesagropastorales-ve-iiie-millenaires-av-j-c-france-approche-bio-anthro pologique/), ETICALP programme (Dir. D. Binder), and new dates have been obtained thanks to the ongoing project INTERACT (ANR-17-FRAL0010, DFG-HA-5407/4-1; Dir. M.-F Deguilloux/W. Haak).

\section{AUTHOR CONTRIBUTIONS}

Anthropological material was partially studied by S. Provost. Isotope studies were conducted by Gwenaëlle Goude and Domingo C. Salazar-García; laboratory assistance was provided by A. Varalli and S. Bernardini. Dental calculus and archaeobotanical analyses were performed by Robert C. Power and Laurent Bouby. Genetic analyses were conducted by Maïté Rivollat, Marie-France Deguilloux, and Marie-Hélène Pemonge. Archaeozoological material was studied and provided for analysis by Lionel Gourichon and M. Vuillien. This pilot study is part of a wider multidisciplinary project which compares other complementary data in particular to document the place of women at the onset of farming. All authors contributed to writing the article under the coordination of GG. The article has been edited by a professional: https://karinagerdau.com/. We are also very grateful to the reviewers and editors for their relevant comments and fruitful corrections and editing which helped to deeply improve the article.

\section{DATA AVAILABILITY STATEMENT}

The authors declare that the data supporting the findings of this study are all available within the article and its supporting information (SI) files. 


\section{ORCID}

Gwenaëlle Goude (ID) https://orcid.org/0000-0002-3008-3607

\section{REFERENCES}

Albert, R. M., Weiner, S., Bar-Yosef, O., \& Meignen, L. (2000). Phytoliths in the Middle Palaeolithic deposits of Kebara Cave, Mt Carmel, Israel: Study of the plant materials used for fuel and other purposes. Journal of Archaeological Science, 27, 931-947.

Ambrose, S. H., \& Norr, L. (1993). Experimental evidence for the relationship of the carbon isotope ratios of whole diet and dietary protein to those of bone collagen and carbonate. In J. B. Lambert \& G. Grupe (Eds.), Prehistoric human bone archaeology at the molecular level (pp. 1-37). Berlin: Springer-Verlag.

Armitage, P. L. (1975). The extraction and identification of opal phytoliths from the teeth of ungulates. Journal of Archaeological Science, 2, 450-455.

Beau, A., Rivollat, M., Reveillas, H., Pemonge, M. H., Mendisco, F., Thomas, Y., ... Deguilloux, M. F. (2017). Multi-scale ancient DNA analyses confirm the western origin of Michelsberg farmers and document probable practices of human sacrifice. PLoS ONE, 12(7), e0179742.

Behre, K. E. (2008). Collected seeds and fruits from herbs as prehistoric food. Vegetation History and Archaeobotany, 17, 65-73.

Bentley, A. R. (2006). Strontium Isotopes from the Earth to the Archaeological Skeleton: A Review. Journal of Archaeological Method and Theory, 13(3), 135-187. http://dx.doi.org/10.1007/s10816-006-9009-x

Bentley, R. A., Bickle, P., Fibiger, L., Nowell, G., Dale, C., Hedges, R., ... Whittle, A. (2012). Community differentiation and kinship among Europe's first farmers. Proceedings of the National Academy of Sciences of the United States of America, 109, 9326-9330.

Berbesque, J. C., Marlowe, F. W., \& Crittenden, A. N. (2011). Sex differences in Hadza eating frequency by food type. American Journal of Human Biology, 23, 339-345.

Biagi, P., \& Starnini, E. (Eds.). (2018). Gli scavi all'Arma dell'Aquila (Finale Ligure, Savona): le ricerche e i materiali degli scavi del Novecento. Trieste: Società per la Preistoria e Protostoria della Regione Friuli-Venezia Giulia.

Binder, D., Battentier, J., Bouby, L., Brochier, J. E., Carré, A., Cucchi, T., ... Thiébault, S. (2020). First farming in the north-western Mediterranean: Evidence from Castellar - Pendimoun during the sixth millennium BCE. In K. Gron, L. Sørensen, \& P. Rowley-Conwy (Eds.), Farmers at the frontier: A pan-European perspective on Neolithisation (pp. 145-159). Oxford/Philadelphia: Oxbow Books.

Binder, D., Battentier, J., Delhon, C., \& Sénépart, I. (2017). In pursuit of a missing transition: The Mesolithic and Neolithic radiocarbon chronology at la Font-aux-Pigeons rock shelter. Antiquity, 91, 605-620.

Binder, D., Lanos, P., Angeli, L., Gomart, L., Guilaine, J., Manen, C., ... Thiébault, S. (2017). Modelling the earliest Western spread of Mediterranean impressed wares: New dates and Bayesian chronological model. Documenta Praehistorica, 44, 54-77.

Binder, D., Lepère, C., \& Maggi, R. (2008). Epipaléolithique et Néolithique dans l'arc liguro-provençal: Bilan et perspectives de la recherche. Bulletin du Musée d'Anthropologie préhistorique de Monaco, Supplément, 1, 49-62.

Bocquet-Appel, J.-P., \& Bar-Yosef, O. (Eds.). (2008). The Neolithic demographic transition and its consequences. London: Springer.

Boessenkool, S., Hanghøj, K., Nistelberger, H. M., Der Sarkissian, C., Gondek, A. T., Orlando, L., ... Star, B. (2017). Combining bleach and mild predigestion improves ancient DNA recovery from bones. Molecular Ecology Resources, 17, 742-751.

Bogaard, A., Heaton, T. H. E., Poulton, P., \& Merbach, I. (2007). The impact of manuring on nitrogen isotope ratios in cereals: Archaeological implications for reconstruction of diet and crop management practices. Journal of Archaeological Science, 34(3), 335-343.
Bouby, L., Durand, F., Rousselet, O., \& Manen, C. (2018). Early farming economy in Mediterranean France: Fruit and seed remains from the early to late Neolithic levels of the site of Taï (ca 5300-3500 cal bc). Vegetation History and Archaeobotany, 28, 17-34. https://doi.org/10. 1007/s00334-018-0683-x

Boyadjian, C. H. C., Eggers, S., \& Scheel-Ybert, R. (2016). Wild harvest: plants in the hominin and pre-agrarian human worlds. In K. Hardy \& L. Kubiak-Martens (Eds.), Evidence of plant foods obtained from the dental calculus of individuals from a Brazilian shell mound, (pp. 215-240). Oxford \& Philadelphia: Oxbow Books.

Budd, P., Montgomery, J., Barreiro, B., \& Thomas, R. G. (2000). Differential diagenesis of strontium in archaeological human dental tissues. Applied Geochemistry, 15(5), 687-694. http://dx.doi.org/10.1016/s0883-2927 (99)00069-4

Cohen, C. (2016). Femmes dans la Préhistoire. Paris, Belin: Springer Verlag, 2018, pp. 1-18.

De Vareilles, A., Bouby, L., Jesus, A., Martin, L., Rottoli, M., Vander, L. M., \& Antolin, F. (2020). One sea but many routes to sail. The early maritime dispersal of Neolithic crops from the Aegean to the western Mediterranean. Journal of Archaeological Science: Reports, 29, 102140. https://doi.org/10.1016/j.jasrep.2019.102140

Delhon, C., Binder, D., Verdin, P., \& Mazuy, A. (2020). Phytoliths as a seasonality indicator? The example of the Neolithic site of Pendimoun, south-eastern France. Vegetation History and Archaeobotany, 29(2), 229-240. https://doi.org/10.1007/s00334-019-00739-0

Dobney, K., \& Brothwell, D. (1986). Dental calculus: Its relevance to ancient diet and oral ecology. In E. Cruwys \& R. A. Foley (Eds.), Teeth and anthropology (Vol. 291, pp. 55-81). Oxford: BAR International Series.

Dobney, K., \& Brothwell, D. (1988). A scanning electron microscope study of archaeological dental calculus. In S. L. Olsen (Ed.), Scanning electron microscopy in archaeology (pp. 372-385). Oxford: BAR International Series.

Drucker, D. G., Valentin, F., Thevenet, C., Mordant, D., Cottiaux, R., Delsate, D., \& Van Neer, W. (2018). Aquatic resources in human diet in the Late Mesolithic in Northern France and Luxembourg: Insights from carbon, nitrogen and Sulphur isotope ratios. Archaeological and Anthropological Sciences, 10(2), 351-368.

Eerkens, J. W., Byrd, B. F., Spero, H. J., \& Fritschi, A. K. (2013). Stable isotope reconstructions of shellfish harvesting seasonality in an estuarine environment: Implications for Late Holocene San Francisco Bay settlement patterns. Journal of Archaeological Science, 40(4), 2014-2024.

Ericson, J. E. (1985). Strontium isotope characterization in the study of prehistoric human ecology. Journal of Human Evolution, 14(5), 503514. http://dx.doi.org/10.1016/s0047-2484(85)80029-4

Evans, J. A., Chenery, C. A., \& Montgomery, J. (2012). A summary of strontium and oxygen isotope variation in archaeological human tooth enamel excavated from Britain. Journal of Analytical Atomic Spectrometry, 27(5), 754-764.

Fahy, G. E., Deter, C., Pitfield, R., Miszkiewicz, J. J., \& Mahoney, P. (2017). Bone deep: Variation in stable isotope ratios and histomorphometric measurements of bone remodelling within adult humans. Journal of Archaeological Science, 87, 10-16.

Faure, G., \& Powell, J. L. (1972). Strontium Isotope Geology, (pp. 189). Berlin, Heidelberg: Springer-Verlag.

France, R. L. (1994). Nitrogen isotopic composition of marine and freshwater invertebrates. Marine Ecology Progress Series, 115, 205-207.

Garcia-Guixé, E., Subirà, M. E., Marlasca, R., \& Richards, M. (2010). $\delta 13 C$ and $\delta 15 \mathrm{~N}$ in ancient and recent fish bones from the Mediterranean Sea. Journal of Nordic Archaeological Science, 17, 83-92.

Goude, G., Binder, D., \& Del Lucchese, A. (2011-2013). Alimentation et modes de vie néolithiques en Ligurie. In M. Bernabo Brea, R. Maggi, \& A. Manfredini (Eds.), II pieno Neolitico in Italia (8-10 juin Finale Ligure 2009) (Vol. 77, pp. 371-387). Finale Ligure: Rivista di Studi Liguri. 
Goude, G., Dori, I., Sparacello, V. S., Starnini, E., \& Varalli, A. (2020). Multiproxy stable isotope analyses of dentine microsections reveal diachronic changes in life history adaptations, mobility, and tuberculosis-induced wasting in prehistoric Liguria (Finale Ligure, Italy, northwestern Mediterranean). International Journal of Paleopathology, 28, 99-111.

Goude, G., \& Fontugne, M. (2016). Carbon and nitrogen isotopic variability in bone collagen during the Neolithic period: Influence of environmental factors and diet. Journal of Archaeological Science, 70, 117-131.

Goude, G., Salazar-Garcia, D. C., Power, R., Terrom, J., Rivollat, M., Deguilloux, M.-F., ... Hauzeur, A. (2019). A multidisciplinary approach to Neolithic life reconstruction. Journal of Archaeological Method and Theory, 26(2), 537-560.

Goude, G., Schmitt, A., Herrscher, E., Loison, G., Cabut, S., \& André, G. (2013). Pratiques alimentaires au Néolithique moyen: Nouvelles données sur le site de Pontcharaud 2 (Auvergne, France). Bulletin de la Société Préhistorique Française, 110(2), 299-317.

Goude, G., Willmes, M., Wood, R., Courtaud, P., Leandri, F., Cesari, J., \& Grün, R. (2017). New insights into mesolithic human diet in the Mediterranean from stable isotope analysis: The sites of Campu Stefanu and Torre d'Aquila, Corsica. International Journal of Osteoarchaeology, 27(4), 707-714. https://doi.org/10.1002/oa.2578

Graustein, W. C. (1989). Stable Isotopes in Ecological Research. In P. W. Rundel, J. R. Ehleringer, \& K. A. Nagy (Eds.), 87Sr/86Sr Ratios Measure the Sources and Flow of Strontium in Terrestrial Ecosystems, (pp. 491512). New York, NY: Springer.

Guiry, E. J., Hillier, M., Boaventura, R., Silva, A. M., Oosterbeek, L., Tomé, T., ... Richards, M. P. (2016). The transition to agriculture in south-western Europe: New isotopic insights from Portugal's Atlantic coast. Antiquity, 90(351), 604-616.

Hammer, Ø., Harper, D. A. T., \& Ryan, P. D. (2001). PAST: Paleontological statistics software package for education and data analysis. Palaeontologia Electronica, 4, 9.

Hansen, C. W., Jensen, P. S., \& Skovsgaard, C. V. (2015). Modern gender roles and agricultural history: The Neolithic inheritance. Journal of Economic Growth, 20(4), 365-404.

Hardy, K., Blakeney, T., Copeland, L., Kirkham, J., Wrangham, R. W., \& Collins, M. J. (2009). Starch granules, dental calculus and new perspectives on ancient diet. Journal of Archaeological Science, 36, 248-255.

Hedges, R., \& Reynard, L. (2007). Nitrogen isotopes and the trophic level of humans in archaeology. Journal of Archaeological Science, 34, 1240-1251.

Henry, A. G., \& Piperno, D. R. (2008). Using plant microfossils from dental calculus to recover human diet: A case study from Tell al-Raqā'i, Syria. Journal of Archaeological Science, 35, 1943-1950.

Herrscher, E., \& Goude, G. (2015). Biogéochimie isotopique et anthropologie. In M. Balasse, J. P. Brugal, Y. Dauphin, E. M. Geigl, M. C. Oberlin, \& I. Reiche (Eds.), Messages d'os Archéométrie du squelette animal et humain (pp. 359-375). Paris: Archives contemporaines.

Holden, C., \& Mace, R. (1999). Sexual dimorphism in stature and women's work: A phylogenetic cross-cultural analysis. American Journal of Physical Anthropology, 110(1), 27-45.

Hoppe, K. A., Koch, P. L., \& Furutani, T. T. (2003). Assessing the preservation of biogenic strontium in fossil bones and tooth enamel. International Journal of Osteoarchaeology, 13(1-2), 20-28. http://dx.doi.org/ 10.1002/oa.663

Humphrey, L. T., Dean, M. C., Jeffries, T. E., \& Penn, M. (2008). Unlocking evidence of early diet from tooth enamel. Proceedings of the National Academy of Sciences, 105(19), 6834-6839. http://dx.doi.org/10.1073/ pnas. 0711513105

Lacan, M., Keyser, C., Ricaut, F.-X., Brucato, N., Duranthon, F., Guilaine, J., ... Ludes, B. (2011). Ancient DNA reveals male diffusion through the Neolithic Mediterranean route. Proceedings of the National Academy of Sciences, 108(24), 9788-9791.
Lanos, P., Philippe, A., Lanos, H., \& Dufresne, P. (2016). Chronomodel: Chronological modelling of archaeological data using Bayesian statistics. (Version 1.5). Retrived from https://chronomodel.com.

Le Bras-Goude, G., Binder, D., Formicola, V., Duday, H., CoutureVeschambre, C., Hublin, J.-J., \& Richards, M. P. (2006). Stratégies de subsistance et analyse culturelle de populations néolithiques de Ligurie: approche par l'étude isotopique (13C et $15 \mathrm{~N})$ des restes osseux. Bulletins et Mémoires de la Société d'Anthropologie de Paris, 18 (1-2), 45-55.

Le Bras-Goude, G., Binder, D., Simon, P., \& Richards, M. P. (2006). L'homme du Rastel (Peillon, Alpes-Maritimes, France): Nouvelles données isotopiques ( $\mathrm{d} 13 \mathrm{C}$ et $\mathrm{d} 15 \mathrm{~N}$ ), radiométriques et archéologiques. Bulletin du Musée d'Anthropologie préhistorique de Monaco, 46, 84-87.

Le Bras-Goude, G., Binder, D., Zemour, A., \& Richards, M. P. (2010). New radiocarbon dates and isotope analysis of Neolithic human and animal bone from Fontbrégoua Cave (Salernes, Var, France). Journal of Anthropological Sciences, 88, 167-178.

Lelli, R., Allen, R., Biondi, G., Calattini, M., Barbaro, C. C., Gorgoglione, M. A., ... Craig, O. E. (2012). Examining dietary variability of the earliest farmers of South-Eastern Italy. American Journal of Physical Anthropology, 149(3), 380-390.

Leonard, C., Vashro, L., O'Connell, J. F., \& Henry, A. G. (2015). Plant microremains in dental calculus as a record of plant consumption: $\mathrm{A}$ test with Twe forager-horticulturalists. Journal of Archaeological Science: Reports, 2, 449-457.

Lightfoot, E., Boneva, B., Miracle, P. T., Šlaus, M., \& O'Connell, T. C. (2011). Exploring the Mesolithic and Neolithic transition in Croatia through isotopic investigations. Antiquity, 85(327), 73-86.

Mannino, M. A., Talamo, S., Goude, G., \& Richards, M. P. (2018). Analisi isotopiche e datazioni sul collagene osseo degli inumati dell'Arma delI'Aquila (Finale Ligure, Savona). In P. Biagi \& E. Starnini (Eds.), Gli scavi all'Arma dell'Aquila (finale ligure, savona): Le ricerche e i materiali degli scavi del novecento (pp. 183-188). Quaderno 15, Trieste: Società per la preistoria e protostoria della regione Friuli-Venezia Giulia.

Marinval, P. (1988). Cueillette, agriculture et alimentation végétale de l'Epipaléolithique jusqu'au 2ème âge du Fer en France méridionale. Apports palethnographiques de la carpologie. Mémoire de thèse, EHESS, Paris, 2 vol., 458 p.

Marinval, P. (1993). Approche carpologique de la néolithisation du sud de la France. In P. C. Anderson (Ed.), Préhistoire de l'agriculture: Nouvelles approches expérimentales et ethnographiques. (Monographies du CRA, 6) (pp. 256-263). Paris: CNRS.

Martin, L., Bouby, L., Marinval, P., Dietsch-Sellami, M. F., Rousselet, O., Cabanis, M., ... Figueiral, I. (2016). L'exploitation des ressources végétales durant le Chasséen: un bilan des données carpologiques en France entre 4400 et 3500 avant notre ère. In T. Perrin, P. Chambon, J. F. Gibaja Bao, \& G. Goude (Eds.), Le Chasséen, des Chasséens... Retour sur une culture nationale et ses parallèles: Sepulcres de fossa, Cortaillod, Lagozza. Actes du colloque international tenu à Paris (France) du 18 au 20 novembre 2014 (pp. 259-272). Toulouse: Archives d'Ecologie Préhistorique.

Mendisco, F., Keyser, C., Hollard, C., Seldes, V., Nielsen, A. E., Crubezy, E., \& Ludes, B. (2011). Application of the iPLEX Gold SNP genotyping method for the analysis of Amerindian ancient DNA samples: Benefits for ancient population studies. Electrophoresis, 32, 386-393. https://doi.org/10.1002/elps.201000483

Metcalfe, C. R., \& Chalk, L. (1950). Anatomy of the dicots. Oxford: The Clarendon Press.

Milner, N., Craig, O. E., Bailey, G. N., Pedersen, K., \& Andersen, S. H. (2004). Something fishy in the Neolithic? A re-evaluation of stable isotope analysis of Mesolithic and Neolithic coastal populations. Antiquity, 78(299), 9-22.

Müller, K., Le Bras-Goude, G., Buscaglia, F., \& Reiche, I. (2009). Human remains from La Pollera: A study of the preservation state, of the 
consolidant and its effect on stable isotope analysis. In 6th international conference on bone diagenesis. Germany: Bonn.

Murail, P., Bruzek, J., Houët, F., \& Cunha, E. (2005). DSP: A tool for probabilistic sex diagnosis using worldwide variability in hip-bone measurement. Bulletins et Mémoires de la Société d'Anthropologie de Paris, 3-4, 167-176.

Nanci, A. (2013). Ten Cate's oral histology: development, structure and function, (pp. 379). St Louis, MO: Elsevier Mosby.

Nehlich, O. (2009). Sulphur isotope analysis of archaeological tissues: A new method for reconstructing past human and animal diet and mobility [PhD] (p. 155). Leipzig: University of leipzig.

Nehlich, O. (2015). The application of sulphur isotope analyses in archaeological research: A review. Earth-Science Reviews, 142, 1-17.

Pearsall, D. M., \& Dinan, E. H. (1992). Developing a phytolith classification system. In J. George Rapp \& S. C. Mulholland (Eds.), Phytolith systematics (pp. 37-64). Springer: Boston, MA.

Pettitt, P. B., Richards, M., Maggi, R., \& Formicola, V. (2003). The Gravettian burial known as The Prince ("Il Principe"): New evidence for his age and diet. Antiquity, 77(295), 15-19.

Piperno, D. R. (2006). Phytoliths: A comprehensive guide for archaeologists and paleoecologists. Lanham: AltaMira.

Pouydebat, E. (1997). Approche biogéochimique de l'alimentation humaine dans le site prénéolithique du Monte Leone (VIIle millénaire av J.-C; Bonifacio Corse-du-Sud) [Mémoire de Maîtrise d'Archéologie]. Université Paris I. $84 \mathrm{p}$.

Power, R. C., Rosen, A. M., \& Nadel, D. (2014). The economic and ritual utilization of plants at the Raqefet Cave Natufian site: The evidence from phytoliths. Journal of Anthropological Archaeology, 33, 49-65.

Power, R. C., Salazar-García, D. C., \& Henry, A. G. (2016). Dental calculus evidence of Gravettian diet and behaviour at Dolní Věstonice and Pavlov. In J. Svoboda (Ed.), Dolní Věstonice II: Chronostratigraphy, Paleoethnology, Paleoanthropology (pp. 345-352). Brno: Academy of Sciences of The Czech Republic, Institute of Archeology.

Power, R. C., Salazar-García, D. C., Rubini, M., Darlas, A., Harvati, K., Walker, M., ... Henry, A. G. (2018). Dental calculus indicates widespread plant use within the stable Neanderthal dietary niche. Journal of Human Evolution, 119, 27-41.

Power, R. C., Salazar-García, D. C., Wittig, R. M., Freiberg, M., \& Henry, A. G. (2015). Dental calculus evidence of Taï Forest Chimpanzee plant consumption and life history transitions. Scientific Reports, 5 , 15161.

Power, R. C., Salazar-García, D. C., Wittig, R. M., \& Henry, A. G. (2014). Assessing use and suitability of scanning electron microscopy in the analysis of micro remains in dental calculus. Journal of Archaeological Science, 49, 160-169.

Price, T. D., Bentley, R. A., Lüning, J., Gronenborn, D., \& Wahl, J. (2001). Prehistoric human migration in the Linearbandkeramik of Central Europe. Antiquity, 75(289), 593-603.

Provost, S., Binder, D., Duday, H., Goude, G., Durrenmath, G., \& Gourichon, L. (2017). avec la collaboration de Castex D., Delhon C., Gentile I., Vuillien M., Zemour A. Une sépulture collective à la transition des 6ème et 5ème millénaires BCE: Mougins - "Les Bréguières» 1 (Alpes-Maritimes, France), fouilles Maurice Sechter 1966-1967. Gallia Préhistoire, 57, 289-338 Retrieved from https://journals. openedition.org/galliap/591

Reimer, P. J., Bard, E., Bayliss, A., Beck, J. W., Blackwell, P. G., Bronk Ramsey, C., ... Van Der Plicht, J. (2013). IntCal13 and Marine13 radiocarbon age calibration curves $0-50,000$ years cal BP. Radiocarbon, 55 1869-1887.

Rey, L., Goude, G., \& Rottier, S. (2017). Comportements alimentaires au Néolithique: nouveaux résultats dans le Bassin parisien à partir de l'étude isotopique $(\delta 13 \mathrm{C}, \delta 15 \mathrm{~N})$ de la nécropole de Gurgy «Les Noisats» (Yonne, Ve millénaire av. J.-C.). Bulletins et Mémoires de la Société d'Anthropologie de Paris, 29, 54-69.
Rey, L., Salazar-Garcìa, D. C., Chambon, P., Santos, F., Rottier, S., \& Goude, G. (2019). A multi-isotope analysis of Neolithic human groups in the Yonne valley, Northern France: Insights into dietary patterns and social structure. Archaeological and Anthropological Sciences, 11, 5591-5616.

Richards, M. P., \& Hedges, R. (1999). Stable isotope evidence for similarities in the types marine food used by late mesolithic humans at sites along the Atlantic coast of Europe. Journal of Archaeological Science, 26, 712-722.

Richards, M. P., \& Schulting, R. J. (2003). Sharp shift in diet at onset of Neolithic. Nature, 425, 366.

Rivollat, M., Mendisco, F., Pemonge, M. H., Safi, A., St-Marc, D., Bremond, A., ... Deguilloux, M. F. (2015). When the waves of European neolithization met: first paleogenetic evidence from early farmers in the southern Paris Basin. PLoS One, 10(4), e0125521. https://doi.org/10.1371/journal.pone.0125521

Salazar-García, D. C., Aura, J. E., Olària, C. R., Talamo, S., Morales, J. V., \& Richards, M. P. (2014). Isotope evidence for the use of marine resources in the Eastern Iberian Mesolithic. Journal of Archaeological Science, 42, 231-240.

Salazar-García, D. C., Fontanals-Coll, M., Goude, G., \& Subirà, M. E. (2018). "To 'seafood' or not to 'seafood'?" An isotopic perspective on dietary preferences at the Mesolithic-Neolithic transition in the Western Mediterranean. Quaternary International, 470, 497-510.

Salazar-García, D. C., Romero, A., García-Borja, P., Subirà, M. E., \& Richards, M. P. (2016). A combined dietary approach using isotope and dental buccal-microwear analysis of human remains from the Neolithic, Roman and Medieval periods from the archaeological site of Tossal de les Basses (Alicante, Spain). Journal of Archaeological Science: Reports, 6, 610-619.

Slovak, N. M., \& Paytan, A. (2012). Applications of Sr Isotopes in Archaeology. In M. Baskaran (Ed.). Handbook of Environmental Isotope Geochemistry: Vol I. (pp. 743-768). Berlin, Heidelberg: Springer.

Savard, M. (2000). Etude de l'assemblage carpologique de la Baume de Fontbrégoua (Var) du Paléolithique final au Chasséen recent (p. 60). Mémoire de DEA: Université de Paris I/Université de Paris X.

Schoeninger, M. J., \& De Niro, M. J. (1983). Nitrogen and carbon isotopic composition of bone collagen from marine and terrestrial animals. Geochimica et Cosmochimica Acta, 48, 625-639.

Schulting, R., \& Richards, M. P. (2002). The wet the wild and the domesticated: The Mesolithic-Neolithic transition of the west of Scotland. European Journal of Archaeology, 5(2), 147-189.

Starnini, E., Biagi, P., \& Mazzucco, N. (2018). The beginning of the Neolithic in the Po Plain (Northern Italy): Problems and perspectives. Quaternary International, 470, 301-317.

Strauss, A., Oliveira, R. E., Bernardo, D. V., Salazar-García, D. C., Talamo, S., Jaouen, K., ... Neves, W. A. (2015). The Oldest Case of Decapitation in the New World (Lapa do Santo, East-Central Brazil). PLOS ONE, 10(9), e0137456. http://dx.doi.org/10.1371/journal.pone.0137456

Szécsényi-Nagy, A., Brandt, G., Haak, W., Keerl, V., Jakucs, J., MöllerRieker, S., ... Alt, K. W. (2015). Tracing the genetic origin of Europe's first farmers reveals insights into their social organization. Proceedings of the Royal Society of London B: Biological Sciences, 282(1805), 20150339.

Szulc, P., Seeman, E., \& Delmas, P. D. (2000). Biochemical measurements of bone turnover in children and adolescents. Osteoporosis International, 11(4), 281-294.

Tauber, H. (1981). $13 \mathrm{C}$ evidence for dietary habits of prehistoric man in Denmark. Nature, 292, 332-333.

Thomas, J. (2003). Thoughts on the 'repacked' Neolithic revolution. Antiquity, 77(295), 67-74.

Twiss, P. C., Suess, E., \& Smith, R. M. (1969). Morphological classification of grass Phytoliths. Soil Science Society of America Proceedings, 33, 109-115.

Umezaki, M., Naito, Y. I., Tsutaya, T., Baba, J., Tadokoro, K., Odani, S., ... Yoneda, M. (2016). Association between sex inequality in animal 
protein intake and economic development in the Papua New Guinea highlands: The carbon and nitrogen isotopic composition of scalp hair and fingernail. American Journal of Physical Anthropology, 159(1), 164-173.

Valentin, J. (2003). Basic anatomical and physiological data for use in radiological protection: Reference values. ICRP Publication 89: Pergamon. Elsevier. 280 p.

Varalli, A., Moggi-Cecchi, J., Moroni, A., \& Goude, G. (2016). Dietary variability during Bronze Age in Central Italie: First results. International Journal of Osteoarchaeology, 26(3), 431-446.

Virginia, R. A., \& Delwiche, C. C. (1982). Natural $15 \mathrm{~N}$ abundance of presumed N2 fixing and non N2 fixing plants from selected ecosystems. Oecologia, 57, 317-325.

Warinner, C., Rodrigues, J. F. M., Vyas, R., Trachsel, C., Shved, N., Grossmann, J., ... Cappellini, E. (2014). Pathogens and host immunity in the ancient human oral cavity. Nature Genetics, 46, 336-344.

Webb, E. C., Lewis, J., Shain, A., Kastrisianaki-Guyton, E., Honch, N. V., Stewart, A., ... Evershed, R. P. (2017). The influence of varying proportions of terrestrial and marine dietary protein on the stable carbon-isotope compositions of pig tissues from a controlled feeding experiment. STAR: Science \& Technology of Archaeological Research, 3(1), 36-52.

Willmes, M., McMorrow, L., Kinsley, L., Armstrong, R., Aubert, M., Eggins, S., ... Grün, R. (2014). The IRHUM (Isotopic Reconstruction of Human
Migration) database - bioavailable strontium isotope ratios for geochemical fingerprinting in France. Earth System Science Data, 6(1), 117-122. http://dx.doi.org/10.5194/essd-6-117-2014

Zazzo, A., Monahan, F. J., Moloney, A. P., Green, S., \& Schmidt, O. (2011). Sulphur isotopes in animal hair track distance to sea. Rapid Communication in Mass Spectrometry, 25, 2371-2378.

Zemour, A., Binder, D., Coppa, A., \& Duday, H. (2016). La sépulture au début du Néolithique (Vle millénaire et première moitié du Ve millénaire cal BC) en France méridionale et en Italie : de l'idée d'une "simple " fosse à une typologie architecturale. Bulletins et Mémoires de la Société d'Anthropologie de Paris, 29(1-2), 94-111. http://dx.doi.org/10.1007/s13219-016-0165-6

\section{SUPPORTING INFORMATION}

Additional supporting information may be found online in the Supporting Information section at the end of this article.

How to cite this article: Goude G, Salazar-García DC, Power RC, et al. New insights on Neolithic food and mobility patterns in Mediterranean coastal populations. Am J Phys

Anthropol. 2020;1-18. https://doi.org/10.1002/ajpa.24089 